\title{
Photocatalytic Oxidation of Natural Organic Matter in Water
}

\author{
Dan C. A. Gowland ${ }^{1}$, Neil Robertson ${ }^{2}$ and Efthalia Chatzisymeon ${ }^{1, *}$ \\ 1 Institute for Infrastructure and Environment, School of Engineering, The University of Edinburgh, \\ Edinburgh EH9 3JL, UK; d.c.a.gowland@sms.ed.ac.uk \\ 2 EaStCHEM School of Chemistry, Joseph Black Building, King's Buildings, Edinburgh EH9 3FJ, UK; \\ neil.robertson@ed.ac.uk \\ * Correspondence: e.chatzisymeon@ed.ac.uk; Tel.: +44-(0)-1316505711
}

check for

updates

Citation: Gowland, D.C.A.; Robertson, N.; Chatzisymeon, E. Photocatalytic Oxidation of Natural Organic Matter in Water. Water 2021,

13, 288. https://doi.org/10.3390/ w13030288

Academic Editor: Antonio Zuorro

Received: 2 December 2020

Accepted: 21 January 2021

Published: 25 January 2021

Publisher's Note: MDPI stays neutral with regard to jurisdictional claims in published maps and institutional affiliations.

Copyright: (C) 2021 by the authors. Licensee MDPI, Basel, Switzerland. This article is an open access article distributed under the terms and conditions of the Creative Commons Attribution (CC BY) license (https:/ / creativecommons.org/licenses/by/ $4.0 /)$.

\begin{abstract}
Increased concentrations of natural organic matter (NOM), a complex mixture of organic substances found in most surface waters, have recently emerged as a substantial environmental issue. NOM has a significant variety of molecular and chemical properties, which in combination with its varying concentrations both geographically and seasonally, introduce the opportunity for an array of interactions with the environment. Due to an observable increase in amounts of NOM in water treatment supply sources, an improved effort to remove naturally-occurring organics from drinking water supplies, as well as from municipal wastewater effluents, is required to continue the development of highly efficient and versatile water treatment technologies. Photocatalysis has received increasing interest from around the world, especially during the last decade, as several investigated processes have been regularly reported to be amongst the best performing water treatment technologies to remove NOM from drinking water supplies and mitigate the formation of disinfection by products. Consequently, this overview highlights recent research and developments on the application of photocatalysis to degrade $\mathrm{NOM}$ by means of $\mathrm{TiO}_{2}$-based heterogeneous and homogeneous photocatalysts. Analytical techniques to quantify NOM in water and hybrid photocatalytic processes are also reviewed and discussed.
\end{abstract}

Keywords: DBPs; AOPs; advanced oxidation processes; fulvic acid; humic acid; wastewater treatment

\section{Introduction}

Natural organic matter (NOM) poses a significant threat to the treatment of drinking water by adding several complications to standard processing methods as well as presenting a substantial risk to public health. NOM is a complex matrix of organic compounds mostly made up of a mixture of humic and fulvic substances including anionic macromolecules of various molecular weights with both aromatic and aliphatic components. Humic acids are mostly made up of larger (10,000 to 100,000 Da) alkaline soluble molecules that vary greatly on the source of material they decay from whereas fulvic acids (fulvates, molecules bound to minerals, and free-form fulvic acids) are usually smaller than humic acids (1000 to 10,000 Da) and are soluble at most $\mathrm{pH}$ levels. NOM levels found in most natural waters range from 0.1 to $20 \mathrm{mg} / \mathrm{L}$, [1-3] however an increase in its concentration in environmental water matrices has been observed recently, [4-6] presenting a strain on current water treatment infrastructure and local ecosystems. This increase in NOM concentration can be attributed to several drastic changes to climate conditions [7-9]. For example, there is a correlation between intensity of precipitation and NOM concentration discharged from forested sites, giving rise to increased runoff intensities and therefore, increased discharge from soils rich in soil organic matter (SOM). Decreased retention time in lake waters, due to climate change induced precipitation, may further cause decreased photochemical degradation of coloured NOM, decreased microbial degradation of complex organic compounds, and decreased in-lake NOM coagulation and sedimentation [10]. Additionally, apparent changes in colour and UV absorption relative to total organic carbon 
(TOC) [11] also imply a change in NOM characteristics and therefore treatability meaning diversification of NOM removal is needed now more than ever [12]. High NOM concentrations can cause aesthetic problems, such as colour and taste [13] in drinking water, as well as higher maintenance and treatment costs of water and wastewater [14,15]. Most importantly, recent studies show that certain classes of NOM can react with chemicals (e.g., chlorine) used in the water treatment process, leading to the formation of carcinogenic disinfection by-products (DBPs) and trihalomethanes (THMs) [16-18]. Since the discovery of DBP formation, several studies have outlined associations between consumption of chlorinated tap water containing elevated THM concentrations and adverse health outcomes, including bladder cancer, [19] children born small for gestational age, [20,21] and miscarriages [22]. Another adverse effect indirectly caused by the presence of NOM in surface waters is the observed interference humic substances have on water treatment processes that are targeting toxic compounds or heavy metals. For example, there has been a significant amount of investigation on the inhibitory effects of NOM on targeted wastewater treatments for residual pharmaceuticals which has been shown to significantly decrease the efficiency of such processes [23-28].

Current alternative treatment techniques for NOM removal, such as coagulation, [29] adsorption, [30] membrane filtration, [31,32] flotation, [33] biological, [15] and ion exchange (IE) [34] processes also bring their own set of problems. For example, the pre-treatment for micro/ultrafiltration systems using conventional treatment processes such as coagulation/flocculation which can partially remove NOM, show low removal efficiency at lower NOM concentrations. Nanofiltration is also sometimes used as a method of NOM removal but additionally comes with the problem of significant membrane fouling [35]. These problems all show a clear need for an alternative method of removing NOM from water resources.

Advanced oxidation processes (AOPs) are widely applied methods for removal of NOM and water treatment [36]. Within the area of AOPs, photocatalysis is an up-andcoming area of research due to its, until recently, untapped wide potential for possible environmental engineering applications. Ongoing research on photocatalytic NOM removal is based around the use of semiconductors (e.g., $\mathrm{TiO}_{2}$ and $\mathrm{ZnO}$ ) as sensitizers for light-induced redox processes. When illuminated with a photon of energy greater than the bandgap energy, these semiconductors form an electron/hole pair. These electron/hole pairs are powerful redox species which many organic photodegradation reactions utilize either directly or indirectly via formation of hydroxyl radicals in solution, $[37,38]$ as shown in Figure 1. Early research tested the capabilities of these reactions using low efficiency UV lamps as $\mathrm{TiO}_{2}$, the most commonly used photocatalyst, has a fairly low visible light absorption. Whereas current work has shifted over to the use of solar and high efficiency light emitting diodes (LEDs) as sustainable photocatalytic irradiation sources [39-44].

Photocatalysis is commonly categorised into either heterogeneous or homogeneous depending on whether the catalyst is in a different phase from the reactants (heterogeneous) or in the same phase (homogeneous). Most common heterogeneous photocatalysts are transition metal oxides and semiconductors, $\mathrm{TiO}_{2}$ being the most researched due to its high photocatalytic activity, excellent physical and chemical stability, low cost, and nontoxicity to humans and the environment. Other common heterogeneous photocatalysts include zinc oxide ( $\mathrm{ZnO})$, which also shows great photocatalytic activity, [45-48] and graphitic carbon nitride $\left(\mathrm{g}-\mathrm{C}_{3} \mathrm{~N}_{4}\right)$, which is being increasingly used because of its preferable bandgap for visible light reactions [49]. Heterogeneous photocatalysis gives practical advantages as it allows easy separation of the reaction media from the catalyst as well as high levels of chemical stability and reusability with many new compounds being developed each day [50-52]. Alternatively, homogeneous photocatalysis may require more complicated steps for catalyst removal but has shown very high photocatalytic activity. The most commonly used homogeneous systems are based on the photo-Fenton process $\left(\mathrm{Fe}^{2+} / \mathrm{H}_{2} \mathrm{O}_{2}\right)$ where the hydroxy radicals produced are the reactive species [53-56]. 


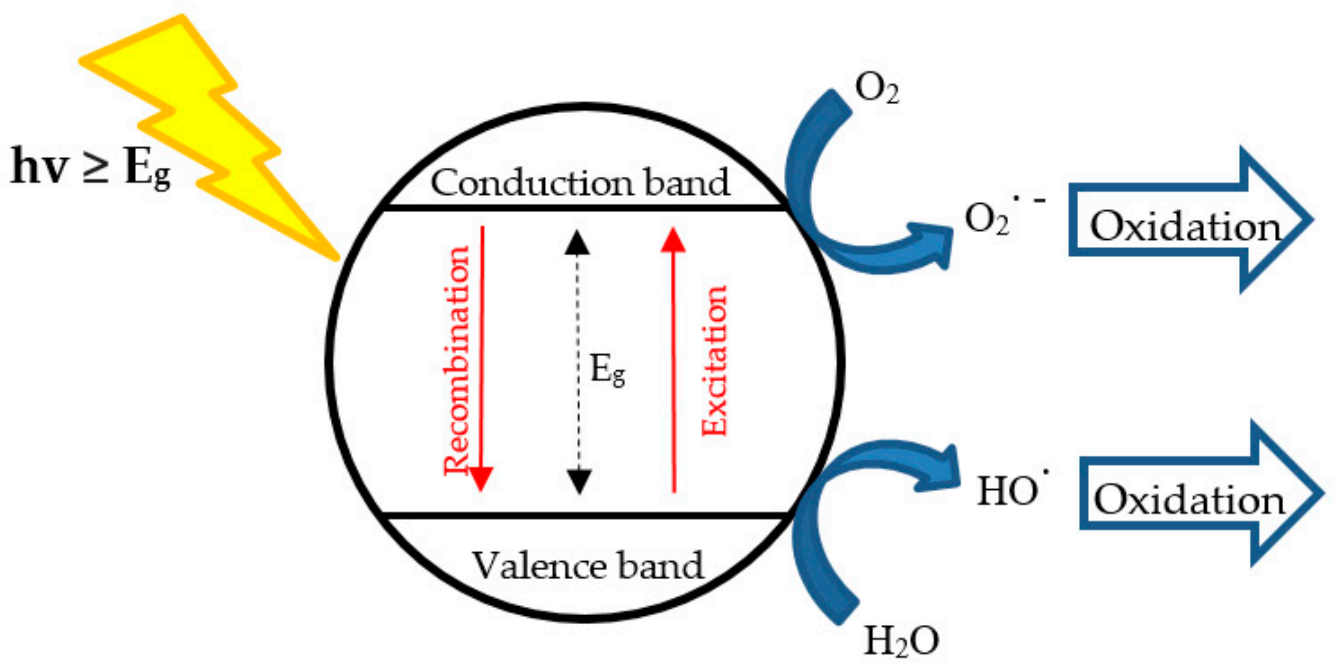

Figure 1. Principle mechanism of photocatalysis.

Increased NOM concentrations in aqueous environment and their adverse effects on human health and ecosystems have been extensively reported. In addition, there are several publications demonstrating that photocatalytic oxidation is a very promising process to remove NOM from water [57]. Nevertheless, a systematic review of all these studies that will be able to summarize all previous research findings, highlight important issues and research areas for further study, as well as suggest new ways to increase the effectiveness and sustainability of existing practices in water and wastewater treatment plants is still missing from literature. Therefore, the aim of this study is to provide a comprehensive review of the work surrounding the photocatalytic treatment and removal of $\mathrm{NOM}$ in water resources. Publications on $\mathrm{TiO}_{2}$-based heterogeneous and homogeneous photocatalytic oxidation are systematically presented and discussed. Recommendations for future research directions and approaches that show promise in advancing these areas are made.

\section{Materials and Methods}

"Natural organic matter", "water", and "wastewater" were used as topic words in searching for papers and patents in Web of Science, Scopus, and Google Scholar (as supplementary) without restriction on publication date. Related documents $(>100)$ were selected to summarize research findings on NOM treatment using photocatalytic degradation as well as other current methods for NOM treatment.

\section{Results and Discussion}

\subsection{Analytical Techniques to Detect and Quantify NOM in Water}

The type and amount of NOM in water substantially varies among different environmental matrices, as it strongly depends on climatic conditions, hydrological regime as well as other environmental factors. Therefore, to monitor NOM concentration during treatment at lab-scale and improve reproducibility of results, synthetic NOM solutions are commonly used. Common procedures involve dissolving humic and/or fulvic acids in ultrapure water and using them to mimic NOM, as humic and fulvic acids represent up to $80 \%$ of the dissolved organics in natural waters and have been shown to be DBP precursors. The reduction of DBP from drinking water is the subject of many NOM related projects, therefore simple, refined humic and fulvic acid samples that are commercially available are typically used by researchers, at least in preliminary testing [58]. More complex NOM samples extracted from water (e.g., International Humic Substances Society (IHSS) samples from the Suwannee River and Mississippi River) have also been known to be used to simulate surface waters as they can give results that more accurately reflect the conditions 
of certain waters in a controlled manner, although they are more expensive than simpler synthetic NOM varieties [59].

Different methods are applied to quantify NOM in water: Specific UV absorbance at $\lambda=254 \mathrm{~nm}$ (SUVA), [60-63] chemical oxygen demand (COD), [64] total organic carbon analyser (TOC), [65,66] fluorescence spectroscopy, [67-70] high performance liquid chromatography (HPLC), [71,72] and mass spectrometric methods (MS) [73,74]. The pros and cons of these commonly used methods are weighed up in Table 1. UV-Vis spectroscopy, in the range of $254-280 \mathrm{~nm}$, is commonly used to measure the presence of unsaturated double bonds and $\pi-\pi$ electron interactions typically found in aromatic compounds such as humic acid. Measuring SUVA is fast, simple, and does not require complicated equipment or chemical reagents making it a popular analytical method in NOM related research. COD utilises an oxidising agent to measure the amount of oxygen needed to oxidise organic matter in solution (permanganate index). This method has been used for a long time due to its simplicity but the many hazardous chemicals (i.e., mercury, hexavalent chromium, sulfuric acid, and silver) involved in the process mean more complex waste management is required than most other methods. Standard COD methods also only allow for COD concentrations that are $>50 \mathrm{mg} / \mathrm{L}$ with alterations to allow for COD detection from 5 to $50 \mathrm{mg} / \mathrm{L}$ [75] making its applications in wastewater management very limited. TOC analysis, considered the main indicator of NOM in the drinking water, determines the organic carbon present in solution by using infrared (IR) spectroscopy to measure the carbon dioxide produced by heat catalysed chemical oxidation with a persulfate solution. Although, compared to UV254 spectroscopy, TOC analysis requires a slightly longer runtime and a more complex preparation, it is still a relatively quick and simple method for quantifying NOM in water with many different available conditions to allow for the tailoring of specific test environments. The chemicals generally required in TOC also have low toxicity and are cheaply available compared to other methods available. Other analytical methods to detect and quantify NOM are also widely used across various disciplines. The complexity of these methods is increased as more information about the NOM's profile is afforded [76-82].

\subsection{NOM Photocatalytic Treatment}

\subsubsection{Heterogeneous $\mathrm{TiO}_{2}$ Photocatalysis}

Table 2 shows all publications focusing on treatment of NOM in water by means of heterogeneous $\mathrm{TiO}_{2}$ photocatalysis. Some of the earliest work on the photocatalytic degradation of $\mathrm{NOM}$ was done by Bekbölet et al. $[83,84]$ where slurries of $\mathrm{P}^{25}-\mathrm{TiO}_{2}$ were used to explore the limitations and general trends observed when changing the reaction conditions in standard photocatalytic procedures. Although these early papers reported on the most favourable conditions for photocatalytic NOM removal, much more work has been done since on optimizing the resultant degradation of NOM by altering basic operational parameters. 
Table 1. Table presenting the main analytical techniques for natural organic matter (NOM) detection and quantification in water.

\begin{tabular}{|c|c|c|c|}
\hline Method & Advantages & Disadvantages & $\begin{array}{l}\text { Complexity of } \\
\text { Method }\end{array}$ \\
\hline $\begin{array}{l}\text { Adsorption } \\
\text { at } 254 \mathrm{~nm}\end{array}$ & $\begin{array}{ll}- & \text { Ease of use } \\
- & \text { Very fast measurement } \\
- & \text { Cheap }\end{array}$ & $\begin{array}{l}\text { - Measurement of unsaturated organics in } \\
\text { water (not only NOM/humic acid) } \\
\text { - High nitrate content in low dissolved organic } \\
\text { carbon (DOC) waters may interfere the } \\
\text { measurement }\end{array}$ & Low \\
\hline COD & $\begin{array}{ll}- & \text { Simple } \\
- & \text { Well known method }\end{array}$ & $\begin{array}{ll}- & \text { Toxic treatment chemicals } \\
- & \text { Low accuracy } \\
- & \text { High minimum detection limit }\end{array}$ & \\
\hline TOC & $\begin{array}{ll}- & \text { Fast measurement } \\
-\quad & \text { Tailorable modes of detection for } \\
\text { specific experiments }\end{array}$ & $\begin{array}{ll}- & \text { Expensive specialised equipment } \\
- & \text { Measurement of total organics in water (not } \\
\text { only NOM/humic acid) }\end{array}$ & \\
\hline $\begin{array}{l}\text { Fluorescence } \\
\text { spectroscopy }\end{array}$ & $\begin{array}{ll}- & \text { No pre-treatment required } \\
- & \text { Gives information on specific NOM }\end{array}$ & $\begin{array}{ll}- & \text { Only detects fluorescent NOM molecules } \\
- & \text { Sensitive to chemical environment, e.g., } \mathrm{pH}\end{array}$ & \\
\hline FTIR & $\begin{array}{ll}- & \text { Good signal to noise ratio } \\
- & \text { Extensive libraries of humic } \\
\text { substances to identify specific } \\
\text { compound characteristics }\end{array}$ & $\begin{array}{l}\text { - } \quad \text { Can see large water band interference } \\
\text { - Pre-treatment could alter chemical makeup } \\
\text { of NOM }\end{array}$ & \\
\hline HPLC & $\begin{array}{l}\text { Good separation of NOM } \\
\text { compounds }\end{array}$ & $\begin{array}{l}\text { - Requires expensive, high purity solvents, } \\
\text { columns etc. } \\
\text { - NOM can have unwanted interactions with } \\
\text { the stationary phase }\end{array}$ & \\
\hline GC-MS & $\begin{array}{l}\text { - Accurate detection of all substances } \\
\text { found in water }\end{array}$ & $\begin{array}{ll}- & \text { Cost of reagents, columns, etc. } \\
- & \text { Difficulty in analysing and interpreting results }\end{array}$ & High \\
\hline
\end{tabular}


Table 2. Publications on heterogeneous photocatalytic treatment of NOM.

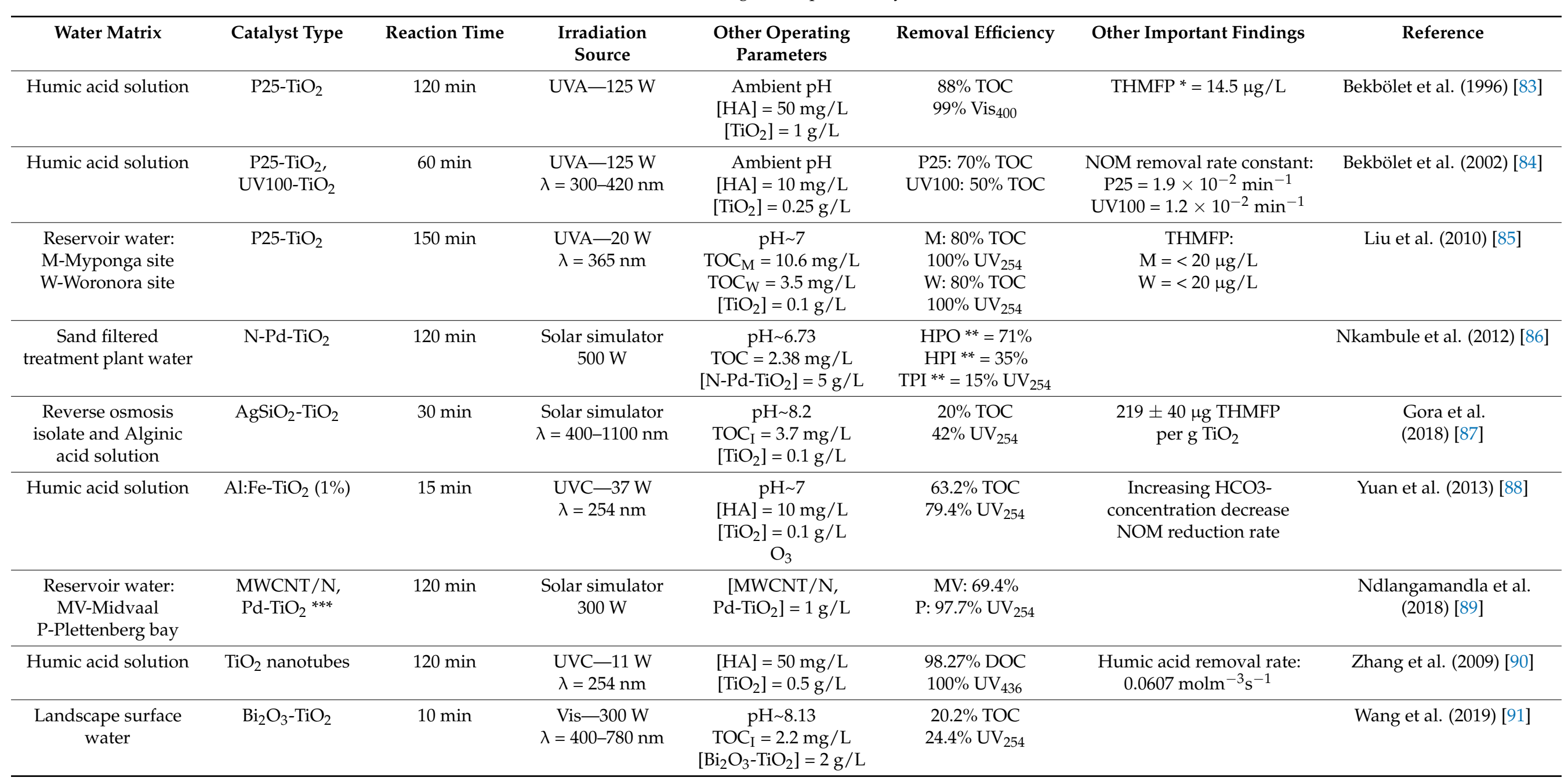


Table 2. Cont.

\begin{tabular}{|c|c|c|c|c|c|c|c|}
\hline Water Matrix & Catalyst Type & Reaction Time & $\begin{array}{l}\text { Irradiation } \\
\text { Source }\end{array}$ & $\begin{array}{c}\text { Other Operating } \\
\text { Parameters }\end{array}$ & Removal Efficiency & Other Important Findings & Reference \\
\hline $\begin{array}{l}\text { Pre-treated } \\
\text { (coagulation- } \\
\text { flocculation) } \\
\quad \text { water }\end{array}$ & $\begin{array}{c}\mathrm{P}_{25}-\mathrm{TiO}_{2} \\
\mathrm{TiO}_{2} / \beta-\mathrm{SiC}\end{array}$ & $220 \mathrm{~min}$ & $\begin{array}{l}\text { Solar simulator- } \\
1500 \mathrm{~W}\end{array}$ & $\begin{array}{c}\mathrm{pH} \sim 6.7 \\
\mathrm{P} 25: \\
\mathrm{TOC}_{\mathrm{I}}=7.8 \mathrm{mg} / \mathrm{L} \\
{\left[\mathrm{TiO}_{2}\right]=0.5 \mathrm{~g} / \mathrm{L}} \\
\beta-\mathrm{SiC}: \\
\mathrm{TOC}_{\mathrm{I}}=5.5 \mathrm{mg} / \mathrm{L} \\
{\left[\mathrm{TiO}_{2}\right]=0.5 \mathrm{~g} / \mathrm{L}}\end{array}$ & $\begin{array}{c}\text { P25: } \\
\text { 80\% TOC } \\
\beta-\mathrm{SiC}: \\
80 \% \text { TOC }\end{array}$ & & Ayekoe et al. (2017) [92] \\
\hline $\begin{array}{l}\text { Treatment plant inlet } \\
\text { water in immersed } \\
\text { ultrafiltration } \\
\text { module }\end{array}$ & $\mathrm{P} 25-\mathrm{TiO}_{2}$ & $\begin{array}{l}120 \text { min } \\
\text { irradiation } \\
43 \mathrm{~h} \text { total } \\
\text { treatment }\end{array}$ & $\begin{array}{l}\text { UVC }-15 \mathrm{~W} \\
\lambda=254 \mathrm{~nm}\end{array}$ & $\begin{array}{c}\mathrm{pH} \sim 7 \\
\mathrm{DOC}=5.48 \mathrm{mg} / \mathrm{L} \\
{\left[\mathrm{TiO}_{2}\right]=0.1 \mathrm{~g} / \mathrm{L}}\end{array}$ & $\begin{array}{c}60 \% \mathrm{DOC} \\
90 \% \mathrm{UV}_{254}\end{array}$ & $\mathrm{THMFP}^{*}=25 \mu \mathrm{g} / \mathrm{L}$ & Rajca et al. (2016) [93] \\
\hline Humic acid solution & $\begin{array}{l}\mathrm{LiCl}-\mathrm{TiO}_{2} \text { doped } \\
\text { PVDF ****} \\
\text { membrane }\end{array}$ & $30 \mathrm{~min}$ & $\begin{array}{l}\text { UVA-100 W } \\
\lambda=365 \mathrm{~nm}\end{array}$ & $\begin{array}{c}\mathrm{pH} \sim 7.5 \\
{[\mathrm{HA}]=2 \mathrm{mg} / \mathrm{L}}\end{array}$ & $80-84 \% \mathrm{UV}_{254}$ & & Song et al. (2014) [94] \\
\hline Extracted river NOM & $\mathrm{P} 25-\mathrm{TiO}_{2}$ & $120 \mathrm{~min}$ & $\begin{array}{l}\text { UVC-8 W } \\
\lambda=254 \mathrm{~nm}\end{array}$ & $\begin{array}{c}\mathrm{pH} \sim 8.2 \\
\mathrm{TOC}_{\mathrm{I}}=10 \mathrm{mg} / \mathrm{L} \\
{\left[\mathrm{TiO}_{2}\right]=1 \mathrm{~g} / \mathrm{L}}\end{array}$ & $\begin{array}{c}80 \% \text { TOC } \\
100 \% U_{254}\end{array}$ & $\begin{array}{l}\text { NOM degradation rate } \\
\text { constant: } 0.0163 \mathrm{~min}^{-1}\end{array}$ & Huang et al. (2008) [95] \\
\hline River water & $\begin{array}{l}\mathrm{Nano}^{-\mathrm{TiO}_{2}} \text { on } \\
\text { diatomite }\end{array}$ & $360 \mathrm{~min}$ & $\begin{array}{c}3 \times \mathrm{UVC} \\
\text { lamps-16 W } \\
\lambda=254 \mathrm{~nm}\end{array}$ & $\begin{array}{c}\mathrm{pH} \sim 8.0-8.5 \\
\mathrm{TOC}_{\mathrm{I}}=9.84- \\
13.18 \mathrm{mg} / \mathrm{L} \\
{\left[\mathrm{TiO}_{2}\right]=0.5 \mathrm{~g} / \mathrm{L}}\end{array}$ & $\begin{array}{l}28.5 \% \text { TOC } \\
40 \% \mathrm{UV}_{254}\end{array}$ & & Sun et al. (2014) [96] \\
\hline Humic acid solution & $\begin{array}{l}\mathrm{TiO}_{2} \text { nanoparti- } \\
\text { cles/granular } \\
\text { activated carbon } \\
\text { (GAC) }\end{array}$ & $180 \mathrm{~min}$ & $\begin{array}{c}\text { UVA-500 W } \\
\lambda=365 \mathrm{~nm}\end{array}$ & $\begin{array}{c}\mathrm{pH} 4.2 \\
\mathrm{TOC}_{\mathrm{I}}=5.04 \mathrm{mg} / \mathrm{L} \\
{\left[\mathrm{TiO}_{2} / \mathrm{GAC}\right]=2 \mathrm{~g} / \mathrm{L}}\end{array}$ & $99.5 \% \mathrm{UV}_{254}$ & $\begin{array}{c}\text { Significantly lower } \\
\text { degradation }\left(70 \% \mathrm{UV}_{254}\right) \text { at } \\
\mathrm{pH}=11\end{array}$ & Xue et al. (2011) [97] \\
\hline
\end{tabular}

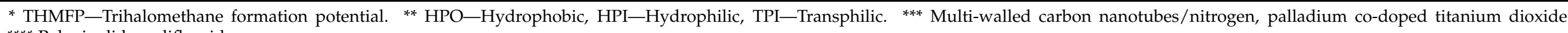
**** Polyvinylidene difluoride. 


\section{Catalyst and NOM Concentration}

The concentration of catalyst is an important parameter for photocatalytic oxidation processes. In general, photocatalytic oxidation is enhanced when catalyst concentration is increased up to a value at which removal rate reaches a plateau. Bekbölet et al. [83] observed that an optimal catalyst concentration for NOM removal is $1 \mathrm{~g} / \mathrm{L}$ and this is high enough to provide a large surface area to adsorb NOM but not so high that the slurry significantly reduces the availability of light throughout the reaction mixture. This upper limit has been noted to depend on the geometry and on the working conditions of the photoreactor [98]. This same study evaluated the trihalomethane formation potential (THMFP) of various humic acid concentrations with respect to time, which also opened up the possibility for more research on the area by showing up to $94 \%$ reductions in THMFP (below the United States Environmental Protection Agency limits) after 120 min of photocatalytic treatment. A similar experiment by Maleki et al. [47] investigated the effects of catalyst concentration on humic acid degradation using $\mathrm{Cu}$-doped $\mathrm{ZnO}$ nanoparticles. The same characteristic rise and plateau in degradation rate was observed when increasing the catalyst concentration from $1.5 \mathrm{~g} / \mathrm{L}$ to $2 \mathrm{~g} / \mathrm{L}$, which was attributed to partial catalyst agglomeration and a consequent decrease in the active catalyst surface at higher dosages of catalysts. Additionally, early work from Palmer et al. [99] on the operational conditions of photocatalytic NOM degradation using $\mathrm{TiO}_{2}$ showed that the rate of initial degradation increased with increasing concentration until the concentration of $30 \mathrm{ppm}$ of carbon, after which, the rate decreased. This trend is seen in several other studies of NOM degradation above 30 ppm of C [100-102].

\section{UV-Light Driven $\mathrm{TiO}_{2}$ Catalysts}

Another early paper by Bekbölet et al. [84] investigated the differences in performance between; the standard $\mathrm{P} 25-\mathrm{TiO}_{2}$, a 20:80 mix of rutile: Anatase titania, and another commercially available HOMBIKAT UV 100- $\mathrm{TiO}_{2}$, made entirely of anatase phase. Here it was shown that $\mathrm{P} 25-\mathrm{TiO}_{2}$ showed better photocatalytic activity when it came to humic acid degradation. This correlated with the adsorption experiments also performed, which revealed that the P25 adsorbed three times as much humic acid at a set loading than the UV100 despite having a much lower BET surface area. Due to its proven high-performance rate $\mathrm{P} 25-\mathrm{TiO}_{2}$ is often the comparative standard used in NOM photocatalytic degradation studies of various semiconductor loadings. Huang et al. [95] in 2008 studied the photocatalysis' effect on NOM by analysing its compositions in water before and after irradiation. There was observed preferential removal of high molecular weight, hydrophobic NOM molecules, which are the major NOM fraction responsible for membrane fouling $[85,86]$. Further research by Valencia et al. [103] using size-exclusion chromatography with respect to operating $\mathrm{pH}$ levels during photocatalytic degradation showed that changes in $\mathrm{pH}$ values affected the adsorption of $\mathrm{NOM}$ onto $\mathrm{TiO}_{2}$. It was established that the $\mathrm{pH}$ determines the mechanism, but not the sequence of the photocatalytic degradation and therefore, regardless of $\mathrm{pH}$, the degradation of the NOM preferentially removed the larger molecular size fraction in comparison to the middle and small fractions. Other comprehensive work on operating parameters includes that done by Espinoza et al. [104] on the effect of metal ions $\left(\mathrm{Cu}^{2+}, \mathrm{Fe}^{3+}, \mathrm{Zn}^{2+}\right.$, and $\left.\mathrm{Mn}^{2+}\right)$ in solution on the photocatalytic degradation of NOM. Photocatalytic degradation experiments with and without the addition of various combinations of $\mathrm{CuSO}_{4}$ or $\mathrm{CuCl}_{2} \cdot 2 \mathrm{H}_{2} \mathrm{O}, \mathrm{FeCl}_{3}, \mathrm{ZnCl}_{2}$, and $\mathrm{MnCl}_{2}$ solutions revealed an apparent reduction in photoactivity and prevention of certain degradation products when in the presence of added $\mathrm{Cu}^{2+}$ ions $(10 \mu \mathrm{M})$. The addition of $\mathrm{Mn}^{2+}$ was observed to change the magnitude of the effect of added $\mathrm{Cu}^{2+}$ a larger inhibiting effect from added $\mathrm{Cu}^{2+}$ was observed in the absence of added $\mathrm{Mn}^{2+}$ during the degradation of large molecular weight NOM. It was suggested by Espinoza et al. that these observations could be explained by a stabilization of the NOM against degradation by $\mathrm{HO}$. by complexation with $\mathrm{Cu}^{2+}$, which would increase the longevity of NOM in aquatic systems. Adding $\mathrm{Fe}^{3+}$ and $\mathrm{Zn}^{2+}$ to the experiments showed no significant effects. 


\section{Visible Light Driven Modified $\mathrm{TiO}_{2}$ Catalysts}

Many investigations on photocatalytic reactions are performed under UV light due to the band gap energy of pure $\mathrm{TiO}_{2}$ ( 3 or $3.2 \mathrm{eV}$ in rutile or anatase phase), which means that there is very limited photocatalytic activity in the visible range. On top of this, unmodified $\mathrm{TiO}_{2}$ can be characterised with a high recombination rate for the photo-produced electron and hole pairs, and a significant difficulty to strongly bind to some support materials [105]. Therefore, a significant amount of research surrounding the photocatalytic degradation of NOM is focussed on improving the photo-efficiency of $\mathrm{TiO}_{2}$ and its degradation efficiency of organic compounds. Various approaches to do so consist of chemical and structural modification of $\mathrm{TiO}_{2}$, in order to enable light absorption in the visible region. These studies include several chemical modification schemes that report promising options to improve photocatalytic activity. Chemical modifications to $\mathrm{TiO}_{2}$ involve the addition of various other species, typically involving: Metals (such as $\mathrm{Fe}$, Pd, or Ag) $[86,88,106,107] /$ metal oxides (such as $\mathrm{Bi}_{2} \mathrm{O}_{3}$ ) [108-111] which can either facilitate electron-hole separation and promote interfacial electron transfer or decrease the $\mathrm{TiO}_{2}$ band gap. This promotes electron transfer from the valence band to the conduction band, facilitating the formation of oxidative species such as hydroxyl radicals [112].

Other chemical modifications include the addition of non-metals (such as C, N, S, or F) which have also been shown to form new impurity levels close to the valence or conduction band of $\mathrm{TiO}_{2}$, thereby lowering the optical gap and shifting the absorption edge to the visible light region [113]. Nkambules [86] 2012 work focuses on $\mathrm{N}$-doped $\mathrm{TiO}_{2}$, a growing area of photocatalysis which has been shown to increase visible light photocatalytic activity when coupled with co-dopant metals by reducing the band gap of $\mathrm{TiO}_{2}$ and shifted the absorption into the visible light region $[89,114]$. The Pd-modified $\mathrm{N}$-doped $\mathrm{TiO}_{2}$ catalyst synthesised by Nkambule et al. in 2012 showed a particularly successful shift in titania's visible light absorption with an over $70 \%$ removal in hydrophobic NOM fractions using a solar simulator. A drawback to these $\mathrm{N}$-doped $\mathrm{TiO}_{2}$ species would be that the doping of $\mathrm{N}$ into the lattice of $\mathrm{TiO}_{2}$ usually results in the formation of oxygen vacancies in the bulk material [115]. These defects can act as recombination centres for carriers and therefore, compared to pure $\mathrm{TiO}_{2}$, a loss of UV-activity is usually found for $\mathrm{N}$-doped $\mathrm{TiO}_{2}$, which is due to the rapid recombination rate of generated electrons and holes introduced by the impurity level. The addition of non-metals to metal doped $\mathrm{TiO}_{2}$ can also be utilised to improve the stability of the photocatalyst, for example forming a thin layer of $\mathrm{SiO}_{2}$ around a catalyst's surface to prevent oxidation of metal nanoparticles like Gora et al. in their 2018 investigation on modified $\mathrm{TiO}_{2}$ for solar photocatalysis [87]. This work saw a $\mathrm{Ag}-\mathrm{TiO}_{2}$ nanoparticle co-catalyst reduce NOM levels by $42 \% \mathrm{UV}_{254}$ only 30 min of treatment time. This study also found significant changes to the disinfectant by-product formation potential (DBPFP) of NOM wherein the different modifications to $\mathrm{TiO}_{2}$ followed the same trend in DBPFP level changes but by differing amounts.

Immobilized Catalysts

Alongside the chemical changes, various nano structured $\mathrm{TiO}_{2}$ materials have been tested with enhanced visible light photoactivity such as nanoparticles, [116] nanotubes, [90] nanowires, [117] and nanofilms [118]. As well as affecting the photoactivity of $\mathrm{TiO}_{2}$, many of these structurally modified materials combat the problems faced by loose slurry reactions such as catalyst separation, recovery, and reuse which bring about significant obstacles for practical applications of $\mathrm{TiO}_{2}$ powder heterogeneous photocatalysis due to its small particle size [119]. Many researchers apply membrane filtration for the separation of nanosized $\mathrm{TiO}_{2}$ from treated water however, as mentioned previously, serious membrane fouling usually occurs as the $\mathrm{TiO}_{2}$ forms a cake layer and blocks membrane pores. Work done by Zhang et al. [90] showed that creating titania nanotubes can not only improve upon $\mathrm{P} 25-\mathrm{TiO}_{2^{\prime}} \mathrm{s}$ ability to photocatalytically degrade $\mathrm{NOM}$, most likely due to increased surface area, but also significantly reduces the amount of membrane fouling caused by catalyst separation. Another approach to reducing the need for catalyst separation when 
photocatalytically degrading NOM is producing hybrid materials by combining $\mathrm{TiO}_{2}$ with carbon materials such as multiwalled carbon nanotubes [89] and activated carbons [97]. A particularly successful example of this is the work done by Xue et al. where a $\mathrm{TiO}_{2}$ nanoparticle/granular activated carbon composite (GAC) was prepared by a sol-dippinggel process. This investigation displayed a synergetic relationship between adsorption upon GAC and degradation involving $\mathrm{TiO}_{2}$ where a humic acid removal of $99.5 \% \mathrm{UV}_{254}$ was achieved as well as improved filterability. Hybrid membranes combining $\mathrm{TiO}_{2}$ with various polymeric compounds such as polyvinylalcohol, pyrrolidone [120] and poly (amideimide) [121] also show a solution to catalyst separation. These hybrid membranes exhibit great potential for water treatment since they combine filtration and photo degradation in a single unit. Although blending photocatalytic nanoparticles into polymeric thin film can cause the entrapped photocatalyst to show reduced catalytic activity due to the agglomeration and shielding effects in the polymer matrix [122].

\section{Hybrid Processes}

The most widely used processes for the removal of NOM from water sources are separation and purification technologies including (micro, ultra, and nano) membrane filtration, reverse or forward osmosis, and coagulation. One approach to improving the overall efficiency of water treatment facilities is combing one or more of these technologies with heterogeneous photocatalysis. This includes the combining of photocatalysts with membrane filtration [93-95,120,123-125] and adsorption, [126] as well as coagulation systems [91]. An example of such systems would be Wang et al. [91] whose work, which showed pre-treatment by photocatalysis with $\mathrm{Bi}_{2} \mathrm{O}_{3}-\mathrm{TiO}_{2}(4 \%)$, could improve the removal of organic matter compared to polyaluminium chloride $(\mathrm{PACl})$ coagulation treatment alone. This study saw removal rates of $20.2 \%$ and $24.4 \% \mathrm{UV}_{254}$ after just $10 \mathrm{~min}$ of photocatalytic treatment which increased to $37.93 \%$ TOC and $58.75 \% \mathrm{UV}_{254}$. Photocatalytic oxidation prior to coagulation has been observed to decrease coagulation efficiency by $15 \%$, most likely because the oxidation changes the characteristics of NOM and degrades NOM molecules towards smaller molecular mass fractions [127]. However, when oxidation was performed after coagulation, about $32 \% \mathrm{DOC}$ and $33 \% \mathrm{UV}_{254}$ enhancements to the removal of NOM occurred [128].

These hybrid processes can also work in tandem to help reduce the inherent downfalls of photocatalytic systems. For example, to ensure an efficient rate of photocatalytic reaction, it is recommended that water turbidity should not exceed 5 NTU $[129,130]$. Although it has been observed that the 5 NTU limit is subjective and differs for each water source and desired treatment level [131]. This limitation on photocatalytic efficiency set by water turbidity means that conventional treatments (i.e., sieving, filtration, sedimentation, coagulation, and flocculation) may be an appropriate industrial pre-treatment for many photocatalytic processes.

\subsubsection{Homogeneous Photocatalysis Photo-Fenton}

Recent interest in homogeneous photocatalytic NOM removal has increased due to reports of lower chemical doses, and therefore, lower residual levels of chemicals post treatment, when compared to conventional NOM removal methods such as coagulation [132]. Although heterogeneous photocatalysis, such as a standard $\mathrm{TiO}_{2} / \mathrm{UV}$ NOM removal, mentioned previously, has the added benefit of easy separation after treatment is completed, homogeneous photocatalysis reactions have the advantage of providing a greater degree of interaction between the catalyst and the specified target due to the increased accessibility of the catalytic sites whilst in solution. The homogeneous photocatalytic degradative removal of organic compounds from water is mainly based on the generation of high amounts of hydroxyl radicals from either ozone or hydrogen peroxide. These generated hydroxyl radicals can degrade the organic matter commonly through hydrogen abstraction from aliphatic carbon atoms and electrophilic addition to double bonds or aromatic rings [133]. 
This is ideal for the degradation of the large hydrophobic NOM fractions which are major precursors for DBP formation [63]. Selected publications on homogeneous photocatalytic NOM treatment are highlighted in Table 3 below.

Table 3. Publications on homogeneous photocatalytic treatment of NOM.

\begin{tabular}{|c|c|c|c|c|c|c|c|}
\hline $\begin{array}{c}\text { Homogeneous } \\
\text { Processes }\end{array}$ & $\begin{array}{l}\text { Water } \\
\text { Matrix }\end{array}$ & $\begin{array}{l}\text { Catalyst } \\
\text { Type }\end{array}$ & $\begin{array}{l}\text { Reaction } \\
\text { Time }\end{array}$ & $\begin{array}{l}\text { Irradiation } \\
\text { Source }\end{array}$ & $\begin{array}{l}\text { Other Operating } \\
\text { Parameters }\end{array}$ & $\begin{array}{l}\text { Removal } \\
\text { Efficiency }\end{array}$ & Reference \\
\hline \multirow[t]{3}{*}{$\begin{array}{l}\text { Hybrid } \\
\text { Photolysis }\end{array}$} & $\begin{array}{l}\text { Reservoir } \\
\text { water }\end{array}$ & $\mathrm{O}_{3} / \mathrm{UV}$ & $60 \mathrm{~min}$ & $\begin{array}{c}\text { UVA lamp } \\
\text { Intensity = } \\
9.7 \mathrm{~mW} / \mathrm{cm}^{2}\end{array}$ & $\begin{array}{c}\mathrm{pH} \sim 6.6 \\
\mathrm{TOC}=1.8 \mathrm{mg} / \mathrm{L} \\
\mathrm{O}_{3} \text { dosage }=0.62 \mathrm{~g} / \mathrm{L}\end{array}$ & $50 \%$ TOC & $\begin{array}{c}\text { Chin and } \\
\text { Bérubé (2005) } \\
\text { [134] }\end{array}$ \\
\hline & River water & $\begin{array}{c}\mathrm{H}_{2} \mathrm{O}_{2} / \mathrm{UV} \\
\mathrm{O}_{3} / \mathrm{UV}\end{array}$ & $30 \mathrm{~min}$ & $\begin{array}{c}\text { UVA } \\
\text { lamp-43 W }\end{array}$ & $\begin{array}{c}\mathrm{TOC}=3.1 \mathrm{mg} / \mathrm{L} \\
{\left[\mathrm{H}_{2} \mathrm{O}_{2}\right]=23 \mathrm{mg} / \mathrm{L}} \\
\mathrm{O}_{3} \text { dosage }=4 \mathrm{mg} / \mathrm{L}\end{array}$ & $\begin{array}{c}\mathrm{H}_{2} \mathrm{O}_{2} \text { only: } \\
3-23 \% \text { DOC } \\
60 \% \mathrm{UV}_{254} \\
\mathrm{O}_{3} \text { only: } \\
31 \% \text { TOC } \\
88 \% \mathrm{UV}_{254}\end{array}$ & $\begin{array}{l}\text { Lamsal et al. } \\
\text { (2011) [135] }\end{array}$ \\
\hline & $\begin{array}{l}\text { Reservoir } \\
\text { water }\end{array}$ & $\mathrm{H}_{2} \mathrm{O}_{2} / \mathrm{UV}$ & - & $\begin{array}{l}\text { UVC lamp } \\
\lambda=254 \mathrm{~nm}\end{array}$ & {$\left[\mathrm{H}_{2} \mathrm{O}_{2}\right]=23 \mathrm{mg} / \mathrm{L}$} & - & $\begin{array}{l}\text { Toor et al. } \\
\text { (2005) [136] }\end{array}$ \\
\hline \multirow[t]{5}{*}{ Photo-Fenton } & $\begin{array}{l}\text { Inlet water to } \\
\text { water } \\
\text { treatment } \\
\text { works }\end{array}$ & $\begin{array}{c}\mathrm{FeSO}_{4} \cdot 7 \mathrm{H}_{2} \mathrm{O} \\
+\mathrm{H}_{2} \mathrm{O}_{2}\end{array}$ & $20 \mathrm{~min}$ & $\begin{array}{c}4 \times \text { UVA } \\
\text { lamps-25 W } \\
\lambda=365 \mathrm{~nm}\end{array}$ & $\begin{array}{c}\mathrm{pH} \sim 4 \\
\mathrm{DOC}=9.6 \mathrm{mg} / \mathrm{L} \\
{[\mathrm{Cat}]=5.65 \mathrm{mg} / \mathrm{L}} \\
\mathrm{H}_{2} \mathrm{O}_{2}: \mathrm{Fe}^{2+}=5: 1\end{array}$ & $\begin{array}{c}90 \% \mathrm{DOC} \\
95 \% \mathrm{UV}_{254}\end{array}$ & $\begin{array}{l}\text { Murray et al. } \\
(2002)[132]\end{array}$ \\
\hline & $\begin{array}{l}\text { Water } \\
\text { treatment } \\
\text { works } \\
\text { reservoir } \\
\text { water }\end{array}$ & $\begin{array}{c}\mathrm{FeSO}_{4} \cdot 7 \mathrm{H}_{2} \mathrm{O} \\
+\mathrm{H}_{2} \mathrm{O}_{2}\end{array}$ & $30 \mathrm{~min}$ & $\begin{array}{c}4 \times \text { UVA } \\
\text { lamps-25 W } \\
\lambda=365 \mathrm{~nm}\end{array}$ & $\begin{array}{c}\mathrm{pH} 4 \\
\mathrm{DOC}=7.5 \mathrm{mg} / \mathrm{L} \\
{\left[\mathrm{Fe}^{2+}\right]=0.1 \mathrm{mM}} \\
\mathrm{H}_{2} \mathrm{O}_{2}: \mathrm{Fe}^{2+}=5: 1\end{array}$ & $\begin{array}{l}90 \% \mathrm{DOC} \\
95 \% \mathrm{UV}_{254}\end{array}$ & $\begin{array}{l}\text { Murray et al. } \\
(2004) \text { [137] }\end{array}$ \\
\hline & $\begin{array}{l}\text { Reservoir } \\
\text { water }\end{array}$ & $\begin{array}{c}\mathrm{FeSO}_{4} \cdot 7 \mathrm{H}_{2} \mathrm{O} \\
+\mathrm{H}_{2} \mathrm{O}_{2} \\
\mathrm{H}_{2} \mathrm{O}_{2} \text { only }\end{array}$ & $1 \mathrm{~min}$ & $\begin{array}{c}4 \times \text { UVC lamp - } \\
12 \mathrm{~W} \\
\lambda=254 \mathrm{~nm}\end{array}$ & $\begin{array}{c}\mathrm{pH} \sim 4.5 \\
\mathrm{DOC}=17.4 \mathrm{mg} / \mathrm{L} \\
{\left[\mathrm{H}_{2} \mathrm{O}_{2}\right]=2.0 \mathrm{mM}} \\
\mathrm{H}_{2} \mathrm{O}_{2}: \mathrm{Fe}^{2+}=4: 1\end{array}$ & $\begin{array}{c}\mathrm{Fe}_{2} \mathrm{SO}_{4} \cdot 7 \mathrm{H}_{2} \mathrm{O}+ \\
\mathrm{H}_{2} \mathrm{O}_{2}: \\
88 \% \mathrm{DOC} \\
31 \% \mathrm{UV}_{254} \\
\mathrm{H}_{2} \mathrm{O}_{2}: \\
78 \% \mathrm{DOC} \\
94 \% \mathrm{UV}_{254}\end{array}$ & $\begin{array}{l}\text { Goslan et al. } \\
(2006) \text { [138] }\end{array}$ \\
\hline & $\begin{array}{l}\text { River water } \\
\text { pre-treated } \\
\text { with slow } \\
\text { sand } \\
\text { filtration }\end{array}$ & $\begin{array}{l}\mathrm{FeCl}_{3} \cdot 7 \mathrm{H}_{2} \mathrm{O} \\
\quad+\mathrm{H}_{2} \mathrm{O}_{2}\end{array}$ & $\begin{array}{c}\text { After } \\
6.5 \mathrm{KJ} / \mathrm{L} \text { of } \\
\text { solar } \\
\text { energy }\end{array}$ & Solar CPC & $\begin{array}{c}\mathrm{pH} \sim 5 \\
\mathrm{DOC}=2.7-3.1 \mathrm{mg} / \mathrm{L} \\
{\left[\mathrm{H}_{2} \mathrm{O}_{2}\right]=20 \mathrm{mg} / \mathrm{L}} \\
{\left[\mathrm{Fe}^{3+}\right]=1 \mathrm{mg} / \mathrm{L}}\end{array}$ & $\begin{array}{l}90 \% \mathrm{DOC} \\
95 \% \mathrm{UV}_{254}\end{array}$ & $\begin{array}{l}\text { Moncayo- } \\
\text { Lasso et al. } \\
(2008) \text { [139] }\end{array}$ \\
\hline & River water & $\begin{array}{l}\mathrm{FeCl}_{3} \cdot 7 \mathrm{H}_{2} \mathrm{O} \\
\quad+\mathrm{H}_{2} \mathrm{O}_{2}\end{array}$ & $\begin{array}{l}\text { After } 20 \\
\mathrm{KJ} / \mathrm{L} \text { of } \\
\text { solar } \\
\text { energy }\end{array}$ & Solar CPC & $\begin{array}{c}\mathrm{pH} \sim 6.5 \\
\mathrm{DOC}=5.5 \mathrm{mg} / \mathrm{L} \\
{\left[\mathrm{H}_{2} \mathrm{O}_{2}\right]=10 \mathrm{mg} / \mathrm{L}} \\
{\left[\mathrm{Fe}^{3+}\right]=0.6 \mathrm{mg} / \mathrm{L}}\end{array}$ & $\begin{array}{l}55 \% \text { DOC } \\
75 \% \mathrm{UV}_{254}\end{array}$ & $\begin{array}{l}\text { Moncayo- } \\
\text { Lasso et al. } \\
(2009)[128]\end{array}$ \\
\hline
\end{tabular}

A comparative study by Goslan et al. [129-138] showed that the addition of Ferrous sulphate increased $\mathrm{UV} / \mathrm{H}_{2} \mathrm{O}_{2}$ ability to remove NOM from reservoir water by forming a photo-Fenton reaction.

$$
\begin{gathered}
\mathrm{Fe}^{3+}+\mathrm{H}_{2} \mathrm{O} \rightarrow \mathrm{Fe}(\mathrm{OH})^{2+}+\mathrm{H}^{+} \\
\mathrm{Fe}(\mathrm{OH})^{2+}+\mathrm{hv} \rightarrow \mathrm{Fe}^{2+}+\cdot \mathrm{OH} \\
\mathrm{Fe}^{2+}+\mathrm{H}_{2} \mathrm{O}_{2} \rightarrow \mathrm{Fe}^{3+}+\mathrm{OH}^{-}+\cdot \mathrm{OH}
\end{gathered}
$$

During the photo-Fenton process, in addition to Equations (2) and (3), hydroxyl radical formation can also occur via the following reactions:

$$
\begin{gathered}
\mathrm{Fe}^{3+}+\mathrm{H}_{2} \mathrm{O}+\mathrm{hv} \rightarrow \mathrm{Fe}^{2+}+\mathrm{H}^{+}+\cdot \mathrm{OH} \\
\mathrm{H}_{2} \mathrm{O}_{2}+\mathrm{hv} \rightarrow 2 \cdot \mathrm{OH}
\end{gathered}
$$

In the photo-Fenton process (Equations (1) and (2)), the Fenton reaction rates are strongly increased by irradiation with UV-vis light. The positive effect of irradiation on 
the degradation rate is due to the photo-chemical regeneration of ferrous iron $\left(\mathrm{Fe}^{2+}\right)$ by photo-reduction of ferric complexes, which leads to additional $\cdot \mathrm{OH}$ generation [140-143]. The ferrous iron generated in solution reacts with $\mathrm{H}_{2} \mathrm{O}_{2}$ yielding a second $\cdot \mathrm{OH}$ radical and ferric ion (Equation (3)), and the cycle continues. A major advantage of the photo-Fenton reagent is that the reactions light absorption maximum wavelength is roughly $600 \mathrm{~nm}$ which gives a much larger absorption overlap with natural sunlight compared to many other common photocatalysts.

Although the exact mechanism used for degradation of NOM using photo-Fenton processes is not presently clear, work from Fukushima et al. [144] has shed some light on possible processes occurring during these degradation reactions. Fukushima's 2001 work on the degradation products produced from degrading several different NOM fractions in a photo-Fenton solution showed that the TOC decreased dependent on increasing irradiation time, indicating mineralisation of the $\mathrm{HA}$ to $\mathrm{CO}_{2}$ during this process. Analysis on different molecular weight fractions of $\mathrm{HA}$ also suggested that the degradation of high molecular weight fractions of HA results in a lowering in molecular size during photo-Fenton processes.

\section{Hybrid Photolytic Oxidation Processes}

An interesting comparison to homogeneous photocatalysis is the work done with homogeneous hybrid photolysis for NOM treatment by enhancing the oxidative capabilities of common oxidising species (e.g., ozone and peroxides) with light. The advantages of these hybrid processes, as well as other AOPs including $\mathrm{O}_{3} / \mathrm{UV}, \mathrm{H}_{2} \mathrm{O}_{2} / \mathrm{UV}$, and $\mathrm{H}_{2} \mathrm{O}_{2} / \mathrm{O}_{3}$, was explored by Lamsal et al. [135] in 2011. This study specifically investigated the treatment process impact on the change of molecular weight distribution (MWD) and disinfection by-product formation potential (DBPFP) with the UV/ozone hybrid showing a significantly improved removal of NOM and reduced DBPFP when compared to UV or ozone treatment alone.

\section{Hydrogen Peroxide Based Photocatalysis}

Many factors decide on the optimum $\mathrm{H}_{2} \mathrm{O}_{2}$ dosage in $\mathrm{UV}$ degradation reactions. For $\mathrm{UV} / \mathrm{H}_{2} \mathrm{O}_{2} \mathrm{NOM}$ removal, the characteristics and concentration of the organic compounds can directly influence the overall mineralisation ability. The amount of hydroxyl radicals produced upon UV irradiation depends on the $\mathrm{H}_{2} \mathrm{O}_{2}$ concentration whilst $\mathrm{H}_{2} \mathrm{O}_{2}$ can also react with these radicals and inhibit hydroxyl radical evolution. Additionally, $\mathrm{H}_{2} \mathrm{O}_{2}$ absorbs UV energy, therefore, reducing the availability of UV photons for oxidising pollutants at higher $\mathrm{H}_{2} \mathrm{O}_{2}$ concentrations. Wang et al. [145] found, for the oxidation of humic acid, that the hydroxyl radical scavenging effect (the production and then combination of $\mathrm{HO}_{2}$ into $\mathrm{H}_{2} \mathrm{O}_{2}$ and $\mathrm{O}_{2}$ ) became significant when the $\mathrm{H}_{2} \mathrm{O}_{2}$ concentration was higher than $0.1 \%$ making this the optimum dosage. This study also noted that the presence of bicarbonate/carbonate species has a negative effect on NOM degradation due to causing competition for hydroxyl radicals, especially at high concentrations of $\mathrm{H}_{2} \mathrm{O}_{2}$.

\section{Ozone Based Photocatalysis}

Ozone can degrade NOM directly through ozonolysis which has been found to be fairly selective and relatively slow [146,147] so most NOM degradation research is focussed on increasing the generation of hydroxyl radicals from the decomposition of ozone in water. This includes the combination of ozone with UV irradiation to degrade NOM through quick, non-selective ozonation. Study results from Ratpukdi et al. [148] on the optimal operating conditions for UV/ozone hybrid photolysis procedures revealed that the mineralization rate of DOC provided by the processes tested ranked in the following order: Vacuum ultraviolet (VUV)/ozone $>$ VUV $>$ UV/ozone $>$ ozone $>$ UV. The study also showed that the highest DOC mineralisation rate and biodegradability increase was at a neutral $\mathrm{pH} 7$ rather than in a basic environment $(\mathrm{pH} 9$ and $\mathrm{pH} 11)$ with extremely basic conditions ( $\mathrm{pH}$ 11) showing no synergistic hybrid effect from combining UV and ozone at all. 
Research comparing $\mathrm{O}_{3} \mathrm{NOM}$ degradation with and without the addition of UVC shows a clear enhancement effect from UV light. Work by Chin and Bérubé [134] concluded that the combined $\mathrm{UV} / \mathrm{O}_{3}$ treatment is more effective at reducing organic constituents, as well as the DBPFP, in raw water than either the ozone or UV treatment alone. Lamsal et al. [129-135] investigated this hybrid effect further by showing how several AOP treatment processes impacted the change of MWD and DBPFP. The UV/ozone hybrid in this side-by-side study showed a significantly improved removal of NOM and reduced DBPFP when compared to UV or ozone treatment alone. It was also noted that this UV/ozone process induced a near complete alteration of the molecular weight of NOM from $>900 \mathrm{Da}$ to $<300 \mathrm{Da}$.

\subsubsection{Energy Efficiency of NOM Treatments}

A significant area of interest surrounding UV photocatalysis is the energy consumption, and associated operating costs, of artificial lighting. The electric energy per order, $\mathrm{E}_{\mathrm{EO}}$, value was introduced by Bolton et al., [149] and is used to estimate the energy consumption of photocatalytic reactors. $\mathrm{E}_{\mathrm{EO}}$ is defined as the energy required for $90 \%$ degradation of a pollutant per cubic meter of contaminated water. $\mathrm{E}_{\mathrm{EO}}\left(\mathrm{kWh} / \mathrm{m}^{3} /\right.$ order $)$, for a batchoperated reactor, is calculated from the following Equation (6):

$$
\mathrm{E}_{\mathrm{EO}}=\frac{\mathrm{P} \times \mathrm{t} \times 1000}{\mathrm{~V} \times 60 \times \log \left(\mathrm{C}_{\mathrm{i}} / \mathrm{C}_{\mathrm{f}}\right)}
$$

where $\mathrm{P}$ is the electrical power of the irradiation source $(\mathrm{kW}), \mathrm{t}$ is the irradiation time (min), $V$ is the volume of the treated effluent $(\mathrm{L})$, and $\mathrm{C}_{\mathrm{i}}$ and $\mathrm{C}_{\mathrm{f}}$ are the initial and final pollutant concentrations $\left(\mathrm{mg} \mathrm{L}^{-1}\right)$, respectively. The $\mathrm{E}_{\mathrm{EO}}$ of selected significant publications are displayed in Table 4 to give an example of the relative energy efficiencies of various photocatalyic NOM treatments.

Table 4. Energy efficiency comparison of photocatalytic treatments of NOM.

\begin{tabular}{|c|c|c|c|c|c|c|c|c|}
\hline $\begin{array}{l}\text { Process } \\
\text { Type }\end{array}$ & Water Matrix & Catalyst Type & $\begin{array}{l}\text { Electrical } \\
\text { Power of the } \\
\text { Irradiation } \\
\text { Source } \\
(P) / k W\end{array}$ & $\begin{array}{l}\text { Reaction } \\
\text { Time } \\
(\mathbf{t}) / \mathrm{min}\end{array}$ & $\begin{array}{l}\text { Volume } \\
\text { (V)/L }\end{array}$ & $\underset{\%}{\text { TOC }}$ & $\begin{array}{c}\mathrm{E}_{\mathrm{EO}} \\
\mathrm{KWh} \mathrm{m}^{-3} \\
\text { Order }^{-1}\end{array}$ & Reference \\
\hline Heterogeneous & Humic acid solution & $\mathrm{P} 25-\mathrm{TiO}_{2}$ & 0.125 & 120 & 0.05 & 88 & 5430 & $\begin{array}{c}\text { Bekbolet } \\
\text { et al. (1996) } \\
\text { [83] }\end{array}$ \\
\hline Heterogeneous & Reservoir water & $\mathrm{P} 25-\mathrm{TiO}_{2}$ & 0.02 & 150 & 0.8 & 100 & 15,625 & $\begin{array}{l}\text { Liu et al. } \\
\text { (2010) [85] }\end{array}$ \\
\hline Heterogeneous & $\begin{array}{c}\text { Pre-treated (coagulation- } \\
\text { flocculation) } \\
\text { water }\end{array}$ & $\mathrm{P} 25-\mathrm{TiO}_{2} / \beta \mathrm{SiC}$ & 1.5 & 220 & 0.1 & 80 & 78,687 & $\begin{array}{c}\text { Ayekoe } \\
\text { et al. (2017) } \\
{[92]}\end{array}$ \\
\hline Homogeneous & River water & $\mathrm{H}_{2} \mathrm{O}_{2} / \mathrm{UV}$ & 0.043 & 30 & 3 & 23 & 63,137 & $\begin{array}{c}\text { Lamsal } \\
\text { et al. }(2010) \\
{[135]}\end{array}$ \\
\hline Homogeneous & River water & $\mathrm{O}_{3} / \mathrm{UV}$ & 0.043 & 30 & 3 & 31 & 44,472 & $\begin{array}{c}\text { Lamsal } \\
\text { et al. }(2011) \\
{[135]}\end{array}$ \\
\hline Homogeneous & $\begin{array}{l}\text { Water treatment works } \\
\text { reservoir water }\end{array}$ & $\mathrm{FeSO}_{4} \cdot 7 \mathrm{H}_{2} \mathrm{O}+\mathrm{H}_{2} \mathrm{O}_{2}$ & 0.1 & 30 & 1 & 90 & 50 & $\begin{array}{c}\text { Murray } \\
\text { et al. (2004) } \\
{[137]}\end{array}$ \\
\hline
\end{tabular}

An interesting observation from the data displayed in Table 4 is the significance the electrical power of the irradiation source $(\mathrm{P})$ plays in the energy efficiency of a reaction. For example, for electrical power $\geq 0.125 \mathrm{~kW}$ the $\mathrm{E}_{\mathrm{EO}}$ is at the order of $10^{3}$ (process types first and third as shown in Table 4), while this decreases to the order of 10 for $\mathrm{P} \leq 0.1 \mathrm{~kW}$. This is due to the position of P on the numerator of Equation (6) which is then multiplied by 1000, 
making relatively small differences in the power inputs of irradiation sources result in large disparities in $\mathrm{E}_{\mathrm{EO}}$. Moreover, when process types with similar $\mathrm{P}$, for example types first and sixth are compared (as shown in Table 4), it can be observed that short treatment time (i.e., $30 \mathrm{~min}$ ) is also important to keep the $\mathrm{E}_{\mathrm{EO}}$ at the low order of $10 \mathrm{KWh} \mathrm{m}^{-3} \mathrm{order}^{-1}$. This shows the significance that recent advancements in LED technology have had for the prospects of industrial scale photocatalytic water treatment due to the drastically improved efficiency when compared to conventional mercury black lights.

\section{Conclusions and Considerations for Future Research}

The removal of NOM from drinking water presents a great challenge that will require the application of efficient and flexible water treatment technology or more likely a combination of synergistic technologies. A crucial process towards achieving this is the proper characterisation of NOM and its various fractions in order to accurately estimate their reactivity with the utilised treatment system. This procedure is critical in the selection and application of the most suitable treatment process by achieving the highest removal efficiency, the greatest reduction in disinfection by-product formation potential, and the best possible cost efficiency. Photocatalysis is highly regarded amongst NOM removal researchers due to the quick and nonselective character of the hydroxyl radicals produced during processing. This makes the measured differences of NOM in water less of an issue in photocatalysis when compared to other conventional NOM removal treatments. Although, various studies reported that photocatalysis can tend to have more impact on NOM's hydrophobic and higher MW compounds [150]. The non-specificity of hydroxy radicals can also be a disadvantage to photocatalytic methods in that the highly reactive $\mathrm{HO}$ can also interact with ions and other dissolved organics in waters which could reduce the overall efficiency of NOM removal. These unintentional side reactions have been observed during the removal of humic acid in the presence of bicarbonate $\left(\mathrm{HCO}_{3}{ }^{-}\right)$and halide $\left(\mathrm{Cl}^{-}\right.$ and $\mathrm{Br}^{-}$) [151-153] ions.

Currently, the coupling of photocatalysis with other water treatment technologies is being investigated as a viable option to overcome the inadequacies of photocatalysis and the selected technology alone. As there is no standalone water treatment technique that is able to optimally remove NOM by itself, numerous integrated processes for the removal of NOM have been studied, such as the combination of photocatalysis with; membrane filtration and adsorption, [93] coagulation, [91] and biodegradation [154].

When focussing on heterogeneous photocatalysis, most research tends to either focus on the optimisation of the photocatalytic activity of $\mathrm{TiO}_{2}$ or to synthesise novel photocatalysts able to compete with $\mathrm{TiO}_{2}$. The improved degradation capabilities of $\mathrm{TiO}_{2}$ are commonly explored via structural modifications (nanocrystals, [155] nanoparticles, [116] nanotubes, [90] nanowires, [117] and nanofilms [118]) and/or combination with other catalysts (ZnO) [156] or materials (polymers, [157] multiwalled carbon nanotubes, [89] and activated carbons [97]). Alternatively, novel photocatalysts are regularly chosen based on their superior photocatalytic activity under near visible or solar light when compared to a $\mathrm{TiO}_{2}$ standard.

Due to large amounts of research focussing on lab scale efficiency, there is an apparent lack of focus on the economics of applying various photocatalytic treatments for the removal of NOM from drinking water sources. This step is crucial to giving a more well-rounded comparison of photocatalytic water treatment with current, well established procedures for NOM removal. Very few publications have evaluated the cost of applying selected photocatalysts for other pollutants, such as immobilised $\mathrm{TiO}_{2}$ for the treatment of industrial wastewaters [158]. Another important factor to consider is the environmental impact of such photocatalytic treatments, life cycle assessments including a goal and scope definition, inventory analysis, and life cycle impact assessment (LCIA) [159] would need to be done to more properly predict the implications of using these systems on an industrial scale. 
Owing to the high energy demand of traditional UV-lamps, alternative sources of UV-light are being investigated. One obvious choice of reducing energy demand of UVlight is the use of sunlight for a lower environmentally impacting and cheap light source. The downside of this being that using solar light is typically less effective as an energy source as its emission spectrum has a relatively small overlap with the absorbance of many common photocatalysts, such as $\mathrm{TiO}_{2}$. This is reflected by the large volume of interest in increasing/red shifting the absorbance wavelength range of $\mathrm{TiO}_{2}$ by doping it with different elements such as nitrogen and carbon [113]. Another possible alternative method of UV illumination is the use of LED reactors due to their high efficiency and durability $[160,161]$.

Developing and applying efficient photocatalysis based technologies to remove NOM and mitigate DBP formations is a promising start and making them more efficient and cost-effective for large scale application in integration with other advanced water treatment technologies is the next crucial step to advancing water treatment engineering.

Author Contributions: Conceptualization, E.C.; methodology, D.C.A.G. investigation, D.C.A.G.; writing-original draft preparation, D.C.A.G.; writing—review and editing, E.C. and N.R.; supervision, E.C. and N.R. All authors have read and agreed to the published version of the manuscript.

Funding: This research was funded by Scottish Water, grant number EP/R513209/1.

Conflicts of Interest: The authors declare no conflict of interest.

\section{References}

1. Volk, C.; Wood, L.; Johnson, B.; Robinson, J.; Zhu, H.W.; Kaplan, L. Monitoring dissolved organic carbon in surface and drinking waters. J. Environ. Monit. 2002, 4, 43-47. [CrossRef] [PubMed]

2. Bolto, B.; Dixon, D.; Eldridge, R.; King, S.; Linge, K. Removal of natural organic matter by ion exchange. Water Res. 2002, 36, 5057-5065. [CrossRef]

3. Reyes, T.G.; Crisosto, J.M. Characterization of Dissolved Organic Matter in River Water by Conventional Methods and Direct Sample Analysis-Time of Flight-Mass Spectrometry. J. Chem. 2016, 2016, 1537370. [CrossRef]

4. Worrall, F.; Harriman, R.; Evans, C.; Watts, C.; Adamson, J.; Neal, C.; Tipping, E.; Burt, T.; Grieve, I.; Monteith, D.; et al. Trends in Dissolved Organic Carbon in UK Rivers and Lakes. Biogeochemistry 2004, 70, 369-402. [CrossRef]

5. Zhang, J.; Hudson, J.; Neal, R.; Sereda, J.; Clair, T.; Turner, M.; Jeffries, D.; Dillon, P.; Molot, L.; Somers, K.; et al. Long-term patterns of dissolved organic carbon in lakes across eastern Canada: Evidence of a pronounced climate effect. Limnol. Oceanogr. 2010, 55, 30-42. [CrossRef]

6. Dong, Q.; Li, P.; Huang, Q.; Abdelhafez, A.A.; Chen, L. Occurrence, polarity and bioavailability of dissolved organic matter in the Huangpu River, China. J. Environ. Sci. 2014, 26, 1843-1850. [CrossRef] [PubMed]

7. Eikebrokk, B.; Vogt, R.D.; Liltved, H. NOM increase in Northern European source waters: Discussion of possible causes and impacts on coagulation/contact filtration processes. Water Supply 2004, 4, 47-54. [CrossRef]

8. Kaal, J.; Plaza, C.; Nierop, K.; Pérez-Rodríguez, M.; Biester, H. Origin of dissolved organic matter in the Harz Mountains (Germany): A thermally assisted hydrolysis and methylation (THM-GC-MS) study. Geoderma 2020, 378, 114635. [CrossRef]

9. Selle, B.; Knorr, K.-H.; Lischeid, G. Mobilisation and transport of dissolved organic carbon and iron in peat catchments-Insights from the Lehstenbach stream in Germany using Generalised Additive Models. Hydrol. Process. 2019, 33, 3213-3225. [CrossRef]

10. Korth, A.; Fiebiger, C.; Bornmann, K.; Schmidt, W. NOM increase in drinking water reservoirs-Relevance for drinking water production. Water Sci. Technol. Water Supply 2004, 4, 55-60. [CrossRef]

11. Grunewald, K.; co-author, as. Increase in Colour and Amount of Organic Matter in Surface Waters, 2003.

12. Ritson, J.P.; Graham, N.J.D.; Templeton, M.R.; Clark, J.M.; Gough, R.; Freeman, C. The impact of climate change on the treatability of dissolved organic matter (DOM) in upland water supplies: A UK perspective. Sci. Total Environ. 2014, 473-474, 714-730. [CrossRef] [PubMed]

13. Leenheer, J.A.; Croué, J.-P. Peer Reviewed: Characterizing Aquatic Dissolved Organic Matter. Environ. Sci. Technol. 2003, 37, 18A-26A. [CrossRef]

14. Costa, A.R.; de Pinho, M.N. Performance and cost estimation of nanofiltration for surface water treatment in drinking water production. Desalination 2006, 196, 55-65. [CrossRef]

15. Krzeminski, P.; Vogelsang, C.; Meyn, T.; Köhler, S.J.; Poutanen, H.; de Wit, H.A.; Uhl, W. Natural organic matter fractions and their removal in full-scale drinking water treatment under cold climate conditions in Nordic capitals. J. Environ. Manag. 2019, 241, 427-438. [CrossRef] [PubMed]

16. Tian, C.; Liu, R.; Liu, H.; Qu, J. Disinfection by-products formation and precursors transformation during chlorination and chloramination of highly-polluted source water: Significance of ammonia. Water Res. 2013, 47, 5901-5910. [CrossRef] [PubMed] 
17. Yang, X.; Guo, W.; Lee, W. Formation of disinfection byproducts upon chlorine dioxide preoxidation followed by chlorination or chloramination of natural organic matter. Chemosphere 2013, 91, 1477-1485. [CrossRef] [PubMed]

18. Pan, Y.; Wang, Y.; Li, A.; Xu, B.; Xian, Q.; Shuang, C.; Shi, P.; Zhou, Q. Detection, formation and occurrence of 13 new polar phenolic chlorinated and brominated disinfection byproducts in drinking water. Water Res. 2017, 112, 129-136. [CrossRef]

19. Costet, N.; Villanueva, C.M.; Jaakkola, J.J.K.; Kogevinas, M.; Cantor, K.P.; King, W.D.; Lynch, C.F.; Nieuwenhuijsen, M.J.; Cordier, S. Water disinfection by-products and bladder cancer: Is there a European specificity? A pooled and meta-analysis of European case-control studies. Occup. Environ. Med. 2011, 68, 379-385. [CrossRef]

20. Wright, J.M.; Evans, A.; Kaufman, J.A.; Rivera-Núñez, Z.; Narotsky, M.G. Disinfection By-Product Exposures and the Risk of Specific Cardiac Birth Defects. Environ. Health Perspect. 2017, 125, 269-277. [CrossRef]

21. Grellier, J.; Bennett, J.; Patelarou, E.; Smith, R.B.; Toledano, M.B.; Rushton, L.; Briggs, D.J.; Nieuwenhuijsen, M.J. Exposure to Disinfection By-products, Fetal Growth, and Prematurity: A Systematic Review and Meta-analysis. Epidemiology 2010, 21, 300-313. [CrossRef]

22. Waller, K.; Swan, S.H.; DeLorenze, G.; Hopkins, B. Trihalomethanes in Drinking Water and Spontaneous Abortion. Epidemiology 1998, 9, 134-140. [CrossRef] [PubMed]

23. De Vietro, N.; Tursi, A.; Beneduci, A.; Chidichimo, F.; Milella, A.; Fracassi, F.; Chatzisymeon, E.; Chidichimo, G. Photocatalytic inactivation of Escherichia coli bacteria in water using low pressure plasma deposited $\mathrm{TiO}_{2}$ cellulose fabric. Photochem. Photobiol. Sci. 2019, 18, 2248-2258. [CrossRef] [PubMed]

24. Davididou, K.; McRitchie, C.; Antonopoulou, M.; Konstantinou, I.; Chatzisymeon, E. Photocatalytic degradation of saccharin under UV-LED and blacklight irradiation. J. Chem. Technol. Biotechnol. 2018, 93, 269-276. [CrossRef]

25. Davididou, K.; Nelson, R.; Monteagudo, J.M.; Durán, A.; Expósito, A.J.; Chatzisymeon, E. Photocatalytic degradation of bisphenol-A under UV-LED, blacklight and solar irradiation. J. Clean. Prod. 2018, 203, 13-21. [CrossRef]

26. Sounthararajah, D.P.; Loganathan, P.; Kandasamy, J.; Vigneswaran, S. Effects of Humic Acid and Suspended Solids on the Removal of Heavy Metals from Water by Adsorption onto Granular Activated Carbon. Int. J. Environ. Res. Public Health 2015, 12, 10475-10489. [CrossRef]

27. Wang, L.; Wei, S.; Jiang, Z. Effects of humic acid on enhanced removal of lead ions by polystyrene-supported nano-Fe (0) nanocomposite. Sci. Rep. 2020, 10, 19663. [CrossRef]

28. Męczykowska, H.; Stepnowski, P.; Caban, M. Impact of humic acids, temperature and stirring on passive extraction of pharmaceuticals from water by trihexyl(tetradecyl)phosphonium dicyanamide. Microchem. J. 2019, 144, 500-505. [CrossRef]

29. Matilainen, A.; Vepsäläinen, M.; Sillanpää, M. Natural organic matter removal by coagulation during drinking water treatment: A review. Adv. Colloid Interface Sci. 2010, 159, 189-197. [CrossRef]

30. Velten, S.; Knappe, D.R.U.; Traber, J.; Kaiser, H.-P.; von Gunten, U.; Boller, M.; Meylan, S. Characterization of natural organic matter adsorption in granular activated carbon adsorbers. Water Res. 2011, 45, 3951-3959. [CrossRef]

31. Petala, M.D.; Zouboulis, A.I. Vibratory shear enhanced processing membrane filtration applied for the removal of natural organic matter from surface waters. J. Membr. Sci. 2006, 269, 1-14. [CrossRef]

32. Winter, J.; Barbeau, B.; Bérubé, P. Nanofiltration and Tight Ultrafiltration Membranes for Natural Organic Matter RemovalContribution of Fouling and Concentration Polarization to Filtration Resistance. Membranes (Basel) 2017, 7, 34. [CrossRef] [PubMed]

33. Zouboulis, A.I.; Jun, W.; Katsoyiannis, I.A. Removal of humic acids by flotation. Colloids Surf. A Physicochem. Eng. Asp. 2003, 231, 181-193. [CrossRef]

34. Boyer, T.H. Removal of Dissolved Organic Matter by Magnetic Ion Exchange Resin. Curr. Pollut. Rep. 2015, 1, 142-154. [CrossRef]

35. Li, Q.; Elimelech, M. Synergistic effects in combined fouling of a loose nanofiltration membrane by colloidal materials and natural organic matter. J. Membr. Sci. 2006, 278, 72-82. [CrossRef]

36. Alrousan, D.; Afkhami, A.; Bani-Melhem, K.; Dunlop, P. Organic Degradation Potential of Real Greywater Using TiO 2 -Based Advanced Oxidation Processes. Water 2020, 12, 2811. [CrossRef]

37. Westerhoff, P.; Aiken, G.; Amy, G.; Debroux, J. Relationships between the structure of natural organic matter and its reactivity towards molecular ozone and hydroxyl radicals. Water Res. 1999, 33, 2265-2276. [CrossRef]

38. Schneider, J.; Matsuoka, M.; Takeuchi, M.; Zhang, J.; Horiuchi, Y.; Anpo, M.; Bahnemann, D.W. Understanding TiO 2 Photocatalysis: Mechanisms and Materials. Chem. Rev. 2014, 114, 9919-9986. [CrossRef]

39. Moreira, N.F.F.; Sousa, J.M.; Macedo, G.; Ribeiro, A.R.; Barreiros, L.; Pedrosa, M.; Faria, J.L.; Pereira, M.F.R.; Castro-Silva, S.; Segundo, M.A.; et al. Photocatalytic ozonation of urban wastewater and surface water using immobilized $\mathrm{TiO}_{2}$ with $\mathrm{LEDs}$ Micropollutants, antibiotic resistance genes and estrogenic activity. Water Res. 2016, 94, 10-22. [CrossRef]

40. Jallouli, N.; Pastrana-Martínez, L.M.; Ribeiro, A.R.; Moreira, N.F.F.; Faria, J.L.; Hentati, O.; Silva, A.M.T.; Ksibi, M. Heterogeneous photocatalytic degradation of ibuprofen in ultrapure water, municipal and pharmaceutical industry wastewaters using a $\mathrm{TiO}_{2}$ /UV-LED system. Chem. Eng. J. 2018, 334, 976-984. [CrossRef]

41. Gao, Y.; Li, S.; Li, Y.; Yao, L.; Zhang, H. Accelerated photocatalytic degradation of organic pollutant over metal-organic framework MIL-53(Fe) under visible LED light mediated by persulfate. Appl. Catal. B Environ. 2017, 202, 165-174. [CrossRef]

42. Martín-Sómer, M.; Pablos, C.; van Grieken, R.; Marugán, J. Influence of light distribution on the performance of photocatalytic reactors: LED vs. mercury lamps. Appl. Catal. B Environ. 2017, 215, 1-7. [CrossRef] 
43. Casado, C.; Timmers, R.; Sergejevs, A.; Clarke, C.T.; Allsopp, D.W.E.; Bowen, C.R.; van Grieken, R.; Marugán, J. Design and validation of a LED-based high intensity photocatalytic reactor for quantifying activity measurements. Chem. Eng. J. 2017, 327, 1043-1055. [CrossRef]

44. Ye, Y.; Feng, Y.; Bruning, H.; Yntema, D.; Rijnaarts, H.H.M. Photocatalytic degradation of metoprolol by $\mathrm{TiO}_{2}$ nanotube arrays and UV-LED: Effects of catalyst properties, operational parameters, commonly present water constituents, and photo-induced reactive species. Appl. Catal. B Environ. 2018, 220, 171-181. [CrossRef]

45. Lee, K.M.; Lai, C.W.; Ngai, K.S.; Juan, J.C. Recent developments of zinc oxide based photocatalyst in water treatment technology: A review. Water Res. 2016, 88, 428-448. [CrossRef] [PubMed]

46. Maleki, A.; Safari, M.; Rezaee, R.; Cheshmeh Soltani, R.D.; Shahmoradi, B.; Zandsalimi, Y. Photocatalytic degradation of humic substances in the presence of $\mathrm{ZnO}$ nanoparticles immobilized on glass plates under ultraviolet irradiation. Sep. Sci. Technol. 2016, 51, 2484-2489. [CrossRef]

47. Maleki, A.; Safari, M.; Shahmoradi, B.; Zandsalimi, Y.; Daraei, H.; Gharibi, F. Photocatalytic degradation of humic substances in aqueous solution using $\mathrm{Cu}$-doped $\mathrm{ZnO}$ nanoparticles under natural sunlight irradiation. Environ. Sci. Pollut. Res. 2015, 22, 16875-16880. [CrossRef] [PubMed]

48. Birben, N.C.; Paganini, M.C.; Calza, P.; Bekbolet, M. Photocatalytic degradation of humic acid using a novel photocatalyst: Ce-doped ZnO. Photochem. Photobiol. Sci. 2017, 16, 24-30. [CrossRef]

49. Wen, J.; Xie, J.; Chen, X.; Li, X. A review on g-C3N4-based photocatalysts. Appl. Surf. Sci. 2017, 391, 72-123. [CrossRef]

50. Ioannidi, A.; Petala, A.; Frontistis, Z. Copper phosphide promoted BiVO4 photocatalysts for the degradation of sulfamethoxazole in aqueous media. J. Environ. Chem. Eng. 2020, 8, 104340. [CrossRef]

51. Tomara, T.; Frontistis, Z.; Petala, A.; Mantzavinos, D. Photocatalytic performance of Ag2O towards sulfamethoxazole degradation in environmental samples. J. Environ. Chem. Eng. 2019, 7, 103177. [CrossRef]

52. Kumaravel, V.; Rhatigan, S.; Mathew, S.; Bartlett, J.; Nolan, M.; Hinder, S.J.; Sharma, P.K.; Singh, A.; Byrne, J.A.; Harrison, J.; et al. Indium-Doped $\mathrm{TiO}_{2}$ Photocatalysts with High-Temperature Anatase Stability. J. Phys. Chem. C 2019, 123, 21083-21096. [CrossRef]

53. Wu, C.-H.; Chang, C.-L. Decolorization of Reactive Red 2 by advanced oxidation processes: Comparative studies of homogeneous and heterogeneous systems. J. Hazard. Mater. 2006, 128, 265-272. [CrossRef] [PubMed]

54. Peternel, I.T.; Koprivanac, N.; Božić, A.M.L.; Kušić, H.M. Comparative study of UV/ $\mathrm{TiO}_{2}, \mathrm{UV} / \mathrm{ZnO}$ and photo-Fenton processes for the organic reactive dye degradation in aqueous solution. J. Hazard. Mater. 2007, 148, 477-484. [CrossRef] [PubMed]

55. Liu, X.; Zhou, Y.; Zhang, J.; Luo, L.; Yang, Y.; Huang, H.; Peng, H.; Tang, L.; Mu, Y. Insight into electro-Fenton and photo-Fenton for the degradation of antibiotics: Mechanism study and research gaps. Chem. Eng. J. 2018, 347, 379-397. [CrossRef]

56. Vorontsov, A.V. Advancing Fenton and photo-Fenton water treatment through the catalyst design. J. Hazard. Mater. 2019, 372, 103-112. [CrossRef]

57. Byrne, J.A.; Dunlop, P.S.M.; Hamilton, J.W.J.; Fernández-Ibáñez, P.; Polo-López, I.; Sharma, P.K.; Vennard, A.S.M. A Review of Heterogeneous Photocatalysis for Water and Surface Disinfection. Molecules 2015, 20, 5574-5615. [CrossRef]

58. Duarte, R.M.B.O.; Santos, E.B.H.; Duarte, A.C. Spectroscopic characteristics of ultrafiltration fractions of fulvic and humic acids isolated from an eucalyptus bleached Kraft pulp mill effluent. Water Res. 2003, 37, 4073-4080. [CrossRef]

59. Ye, Y.; Bruning, H.; Liu, W.; Rijnaarts, H.; Yntema, D. Effect of dissolved natural organic matter on the photocatalytic micropollutant removal performance of $\mathrm{TiO}_{2}$ nanotube array. J. Photochem. Photobiol. A Chem. 2019, 371, 216-222. [CrossRef]

60. Korshin, G.V.; Benjamin, M.M.; Li, C.-W. Use of differential spectroscopy to evaluate the structure and reactivity of humics. Water Sci. Technol. 1999, 40, 9-16. [CrossRef]

61. Ates, N.; Kitis, M.; Yetis, U. Formation of chlorination by-products in waters with low SUVA-correlations with SUVA and differential UV spectroscopy. Water Res. 2007, 41,4139-4148. [CrossRef]

62. Sambo, S.P.; Marais, S.S.; Msagati, T.A.M.; Mamba, B.B.; Nkambule, T.T.I. Quantification of biodegradable natural organic matter (NOM) fractions and its impact on bacterial regrowth in a South African Water Treatment Plant. J. Water Process Eng. 2020, 36, 101332. [CrossRef]

63. Hua, L.-C.; Chao, S.-J.; Huang, K.; Huang, C. Characteristics of low and high SUVA precursors: Relationships among molecular weight, fluorescence, and chemical composition with DBP formation. Sci. Total Environ. 2020, 727, 138638. [CrossRef] [PubMed]

64. Walton, J.; Labine, P.; Reidies, A. The chemistry of permanganate in degradative oxidations. In Chemical Oxidation; Technomic Publishing Co., Inc.: Lancaster, PA, USA, 1991; pp. 205-219.

65. Wallace, B.; Purcell, M.; Furlong, J. Total organic carbon analysis as a precursor to disinfection byproducts in potable water: Oxidation technique considerations. J. Environ. Monit. JEM 2002, 4, 35-42. [CrossRef] [PubMed]

66. Kiashemshaki, H.; Mahvi, A.H.; Najafpoor, A.A.; Hosseinzadeh, A. Investigation of the Efficiency of the Conventional Water Treatment Processes Employed to Eliminate TOC in Jalaliyeh Water Treatment Plant, Tehran. Health Scope 2017, 6, e61907. [CrossRef]

67. Baker, A.; Tipping, E.; Thacker, S.A.; Gondar, D. Relating dissolved organic matter fluorescence and functional properties. Chemosphere 2008, 73, 1765-1772. [CrossRef] [PubMed]

68. Bieroza, M.; Baker, A.; Bridgeman, J. Relating freshwater organic matter fluorescence to organic carbon removal efficiency in drinking water treatment. Sci. Total Environ. 2009, 407, 1765-1774. [CrossRef] 
69. Peiris, R.H.; Hallé, C.; Budman, H.; Moresoli, C.; Peldszus, S.; Huck, P.M.; Legge, R.L. Identifying fouling events in a membranebased drinking water treatment process using principal component analysis of fluorescence excitation-emission matrices. Water Res. 2010, 44, 185-194. [CrossRef]

70. Khamis, K.; Bradley, C.; Hannah, D.M. High frequency fluorescence monitoring reveals new insights into organic matter dynamics of an urban river, Birmingham, UK. Sci. Total Environ. 2020, 710, 135668. [CrossRef]

71. Allpike, B.P.; Heitz, A.; Joll, C.A.; Kagi, R.I. A new organic carbon detector for size exclusion chromatography. J. Chromatogr. A 2007, 1157, 472-476. [CrossRef]

72. Brezinski, K.; Gorczyca, B. An overview of the uses of high performance size exclusion chromatography (HPSEC) in the characterization of natural organic matter (NOM) in potable water, and ion-exchange applications. Chemosphere 2019, 217, 122-139. [CrossRef]

73. Mawhinney, D.B.; Rosario-Ortiz, F.L.; Baik, S.; Vanderford, B.J.; Snyder, S.A. Characterization of fulvic acids by liquid chromatography-quadrupole time-of-flight mass spectrometry. J. Chromatogr. A 2009, 1216, 1319-1324. [CrossRef] [PubMed]

74. Zhang, X.; Han, J.; Zhang, X.; Shen, J.; Chen, Z.; Chu, W.; Kang, J.; Zhao, S.; Zhou, Y. Application of Fourier transform ion cyclotron resonance mass spectrometry to characterize natural organic matter. Chemosphere 2020, 260, 127458. [CrossRef] [PubMed]

75. Huck, P.M. Measurement of Biodegradable Organic Matter and Bacterial Growth Potential in Drinking Water. J. Awwa 1990, 82, 78-86. [CrossRef]

76. Spencer, R.G.M.; Bolton, L.; Baker, A. Freeze/thaw and pH effects on freshwater dissolved organic matter fluorescence and absorbance properties from a number of UK locations. Water Res. 2007, 41, 2941-2950. [CrossRef] [PubMed]

77. Kanokkantapong, V.; Marhaba, T.F.; Panyapinyophol, B.; Pavasant, P. FTIR evaluation of functional groups involved in the formation of haloacetic acids during the chlorination of raw water. J. Hazard. Mater. 2006, 136, 188-196. [CrossRef]

78. Her, N.; Amy, G.; Chung, J.; Yoon, J.; Yoon, Y. Characterizing dissolved organic matter and evaluating associated nanofiltration membrane fouling. Chemosphere 2008, 70, 495-502. [CrossRef]

79. Folhas, D.; Duarte, A.C.; Pilote, M.; Vincent, W.F.; Freitas, P.; Vieira, G.; Silva, A.M.S.; Duarte, R.M.B.O.; Canário, J. Structural Characterization of Dissolved Organic Matter in Permafrost Peatland Lakes. Water 2020, 12, 3059. [CrossRef]

80. Pelekani, C.; Newcombe, G.; Snoeyink, V.L.; Hepplewhite, C.; Assemi, S.; Beckett, R. Characterization of Natural Organic Matter Using High Performance Size Exclusion Chromatography. Environ. Sci. Technol. 1999, 33, 2807-2813. [CrossRef]

81. Zhou, Q.; Cabaniss, S.E.; Maurice, P.A. Considerations in the use of high-pressure size exclusion chromatography (HPSEC) for determining molecular weights of aquatic humic substances. Water Res. 2000, 34, 3505-3514. [CrossRef]

82. Wu, F.C.; Evans, R.D.; Dillon, P.J. Separation and Characterization of NOM by High-Performance Liquid Chromatography and On-Line Three-Dimensional Excitation Emission Matrix Fluorescence Detection. Environ. Sci. Technol. 2003, 37, 3687-3693. [CrossRef]

83. Bekbölet, M.; Özkösemen, G. A preliminary investigation on the photocatalytic degradation of a model humic acid. Water Sci. Technol. 1996, 33, 189-194. [CrossRef]

84. Bekbolet, M.; Suphandag, A.S.; Uyguner, C.S. An investigation of the photocatalytic efficiencies of $\mathrm{TiO}_{2}$ powders on the decolourisation of humic acids. J. Photochem. Photobiol. A Chem. 2002, 148, 121-128. [CrossRef]

85. Liu, S.; Lim, M.; Fabris, R.; Chow, C.; Drikas, M.; Amal, R. Comparison of photocatalytic degradation of natural organic matter in two Australian surface waters using multiple analytical techniques. Org. Geochem. 2010, 41, 124-129. [CrossRef]

86. Nkambule, T.I.; Kuvarega, A.T.; Krause, R.W.M.; Haarhoff, J.; Mamba, B.B. Synthesis and characterisation of Pd-modified $\mathrm{N}$-doped $\mathrm{TiO}_{2}$ for photocatalytic degradation of natural organic matter (NOM) fractions. Environ. Sci. Pollut. Res. 2012, 19, 4120-4132. [CrossRef]

87. Gora, S.; Sokolowski, A.; Hatat-Fraile, M.; Liang, R.; Zhou, Y.N.; Andrews, S. Solar photocatalysis with modified TiO 2 photocatalysts: Effects on NOM and disinfection byproduct formation potential. Environ. Sci. Water Res. Technol. 2018, 4, $1361-1376$. [CrossRef]

88. Yuan, R.; Zhou, B.; Hua, D.; Shi, C. Enhanced photocatalytic degradation of humic acids using $\mathrm{Al}$ and $\mathrm{Fe}_{\text {co-doped TiO }}$ nanotubes under UV/ozonation for drinking water purification. J. Hazard. Mater. 2013, 262, 527-538. [CrossRef]

89. Ndlangamandla, N.G.; Kuvarega, A.T.; Msagati, T.A.M.; Mamba, B.B.; Nkambule, T.T.I. A novel photodegradation approach for the efficient removal of natural organic matter (NOM) from water. Phys. Chem. Earth Parts A/B/C 2018, 106, 97-106. [CrossRef]

90. Zhang, X.; Pan, J.H.; Fu, W.; Du, A.J.; Sun, D.D. $\mathrm{TiO}_{2}$ nanotube photocatalytic oxidation for water treatment. Water Supply 2009, 9 , 45-49. [CrossRef]

91. Wang, N.; Li, X.; Yang, Y.; Shang, Y.; Zhuang, X.; Li, H.; Zhou, Z. Combined process of visible light irradiation photocatalysiscoagulation enhances natural organic matter removal: Optimization of influencing factors and mechanism. Chem. Eng. J. 2019, 374, 748-759. [CrossRef]

92. Ayekoe, C.Y.P.; Robert, D.; Lanciné, D.G. Combination of coagulation-flocculation and heterogeneous photocatalysis for improving the removal of humic substances in real treated water from Agbô River (Ivory-Coast). Catal. Today 2017, 281, 2-13. [CrossRef]

93. Rajca, M. The effectiveness of removal of nom from natural water using photocatalytic membrane reactors in PMR-UF and PMR-MF modes. Chem. Eng. J. 2016, 305, 169-175. [CrossRef]

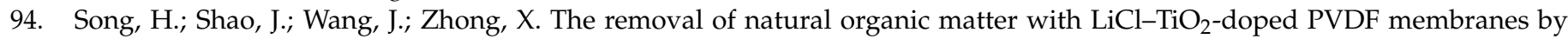
integration of ultrafiltration with photocatalysis. Desalination 2014, 344, 412-421. [CrossRef] 
95. Huang, X.; Leal, M.; Li, Q. Degradation of natural organic matter by $\mathrm{TiO}_{2}$ photocatalytic oxidation and its effect on fouling of low-pressure membranes. Water Res. 2008, 42, 1142-1150. [CrossRef]

96. Sun, W.; Chu, H.; Dong, B.; Cao, D.; Zheng, S. The Degradation of Natural Organic Matter in Surface Water by a Nano$\mathrm{TiO}_{2}$ / Diatomite Photocatalytic Reactor. Clean-SoilAirWater 2014, 42, 1190-1198. [CrossRef]

97. Xue, G.; Liu, H.; Chen, Q.; Hills, C.; Tyrer, M.; Innocent, F. Synergy between surface adsorption and photocatalysis during degradation of humic acid on $\mathrm{TiO}_{2}$ /activated carbon composites. J. Hazard. Mater. 2011, 186, 765-772. [CrossRef]

98. Herrmann, J.-M. Heterogeneous photocatalysis: Fundamentals and applications to the removal of various types of aqueous pollutants. Catal. Today 1999, 53, 115-129. [CrossRef]

99. Palmer, F.L.; Eggins, B.R.; Coleman, H.M. The effect of operational parameters on the photocatalytic degradation of humic acid. J. Photochem. Photobiol. A Chem. 2002, 148, 137-143. [CrossRef]

100. Joolaei, H.; Vossoughi, M.; Rashidi Mehr Abadi, A.; Heravi, A. Removal of humic acid from aqueous solution using photocatalytic reaction on perlite granules covered by $\mathrm{Nano} \mathrm{TiO}_{2}$ particles. J. Mol. Liq. 2017, 242, 357-363. [CrossRef]

101. Babel, S.; Sekartaji, P.A.; Sudrajat, $\mathrm{H}$. $\mathrm{TiO}_{2}$ as an effective nanocatalyst for photocatalytic degradation of humic acid in water environment. J. Water Supply Res. Technol.-AQUA 2016, 66, 25-35. [CrossRef]

102. Song, L.; Zhu, B.; Jegatheesan, V.; Gray, S.R.; Duke, M.C.; Muthukumaran, S. Effect of Hybrid Photocatalysis and Ceramic Membrane Filtration Process for Humic Acid Degradation. In Water Scarcity and Ways to Reduce the Impact: Management Strategies and Technologies for Zero Liquid Discharge and Future Smart Cities; Pannirselvam, M., Shu, L., Griffin, G., Philip, L., Natarajan, A., Hussain, S., Eds.; Springer International Publishing: Cham, Switzerland, 2019; pp. 95-113.

103. Valencia, S.; Marín, J.; Velásquez, J.; Restrepo, G.; Frimmel, F.H. Study of pH effects on the evolution of properties of brown-water natural organic matter as revealed by size-exclusion chromatography during photocatalytic degradation. Water Res. 2012, 46, 1198-1206. [CrossRef]

104. Tercero Espinoza, L.A.; ter Haseborg, E.; Weber, M.; Karle, E.; Peschke, R.; Frimmel, F.H. Effect of selected metal ions on the photocatalytic degradation of bog lake water natural organic matter. Water Res. 2011, 45, 1039-1048. [CrossRef]

105. Di Paola, A.; García-López, E.; Marcì, G.; Palmisano, L. A survey of photocatalytic materials for environmental remediation. J. Hazard. Mater. 2012, 211-212, 3-29. [CrossRef]

106. Birben, N.C.; Uyguner-Demirel, C.S.; Kavurmaci, S.S.; Gürkan, Y.Y.; Turkten, N.; Cinar, Z.; Bekbolet, M. Application of Fe-doped $\mathrm{TiO}_{2}$ specimens for the solar photocatalytic degradation of humic acid. Catal. Today 2017, 281, 78-84. [CrossRef]

107. Sharma, P.K.; Cortes, M.A.L.R.M.; Hamilton, J.W.J.; Han, Y.; Byrne, J.A.; Nolan, M. Surface modification of TiO 2 with copper clusters for band gap narrowing. Catal. Today 2019, 321-322, 9-17. [CrossRef]

108. Sood, S.; Mehta, S.K.; Sinha, A.S.K.; Kansal, S.K. $\mathrm{Bi}_{2} \mathrm{O}_{3} / \mathrm{TiO}_{2}$ heterostructures: Synthesis, characterization and their application in solar light mediated photocatalyzed degradation of an antibiotic, ofloxacin. Chem. Eng. J. 2016, 290, 45-52. [CrossRef]

109. Liu, Y.; Xin, F.; Wang, F.; Luo, S.; Yin, X. Synthesis, characterization, and activities of visible light-driven $\mathrm{Bi}_{2} \mathrm{O}_{3}-\mathrm{TiO}_{2}$ composite photocatalysts. J. Alloy Compd. 2010, 498, 179-184. [CrossRef]

110. Geng, N.; Chen, W.; Xu, H.; Lin, T.; Ding, M.; Wang, Y.; Tao, H.; Hu, K. Preparation of $\mathrm{Fe}_{3} \mathrm{O}_{4} / \mathrm{TiO}_{2}-\mathrm{N}-\mathrm{GO}$ sonocatalyst and using for humic acid removal with the assist of ultrasound. Mater. Sci. Semicond. Process. 2019, 102, 104593. [CrossRef]

111. Khan, S.; Kim, J.; Sotto, A.; Van der Bruggen, B. Humic acid fouling in a submerged photocatalytic membrane reactor with binary $\mathrm{TiO}_{2}-\mathrm{ZrO}_{2}$ particles. J. Ind. Eng. Chem. 2015, 21, 779-786. [CrossRef]

112. Kumar, S.G.; Devi, L.G. Review on Modified $\mathrm{TiO}_{2}$ Photocatalysis under UV/Visible Light: Selected Results and Related Mechanisms on Interfacial Charge Carrier Transfer Dynamics. J. Phys. Chem. A 2011, 115, 13211-13241. [CrossRef]

113. Dozzi, M.V.; Selli, E. Doping $\mathrm{TiO}_{2}$ with p-block elements: Effects on photocatalytic activity. J. Photochem. Photobiol. C Photochem. Rev. 2013, 14, 13-28. [CrossRef]

114. Zhang, J.; Wu, Y.; Xing, M.; Leghari, S.A.K.; Sajjad, S. Development of modified N doped $\mathrm{TiO}_{2}$ photocatalyst with metals, nonmetals and metal oxides. Energy Environ. Sci. 2010, 3, 715-726. [CrossRef]

115. Sakthivel, S.; Janczarek, M.; Kisch, H. Visible Light Activity and Photoelectrochemical Properties of Nitrogen-Doped TiO 2 . J. Phys. Chem. B 2004, 108, 19384-19387. [CrossRef]

116. Gora, S.L.; Andrews, S.A. Adsorption of natural organic matter and disinfection byproduct precursors from surface water onto $\mathrm{TiO}_{2}$ nanoparticles: $\mathrm{pH}$ effects, isotherm modelling and implications for using $\mathrm{TiO}_{2}$ for drinking water treatment. Chemosphere 2017, 174, 363-370. [CrossRef]

117. Zhang, X.; Pan, J.H.; Du, A.J.; Fu, W.; Sun, D.D.; Leckie, J.O. Combination of one-dimensional TiO 2 nanowire photocatalytic oxidation with microfiltration for water treatment. Water Res. 2009, 43, 1179-1186. [CrossRef]

118. Rizzo, L.; Uyguner, C.S.; Selcuk, H.; Bekbolet, M.; Anderson, M. Activation of solgel titanium nanofilm by UV illumination for NOM removal. Water Sci. Technol. 2007, 55, 113-118. [CrossRef]

119. Lee, S.-A.; Choo, K.-H.; Lee, C.-H.; Lee, H.-I.; Hyeon, T.; Choi, W.; Kwon, H.-H. Use of Ultrafiltration Membranes for the Separation of $\mathrm{TiO}_{2}$ Photocatalysts in Drinking Water Treatment. Ind. Eng. Chem. Res. 2001, 40, 1712-1719. [CrossRef]

120. Ng, H.K.M.; Sabran, A.H.; Leo, C.P.; Ahmad, A.L.; Abdullah, A.Z. Photocatalysts in polysulfone membrane for the removal of humic acid: The effects of PVP and PVa on membrane morphology, separation performance and catalytic hindrance. J. Membr. Sci. Res. 2016, 2, 95-101. 
121. Rajesh, S.; Senthilkumar, S.; Jayalakshmi, A.; Nirmala, M.T.; Ismail, A.F.; Mohan, D. Preparation and performance evaluation of poly (amide-imide) and $\mathrm{TiO}_{2}$ nanoparticles impregnated polysulfone nanofiltration membranes in the removal of humic substances. Colloids Surf. A Physicochem. Eng. Asp. 2013, 418, 92-104. [CrossRef]

122. Ballari, M.d.1.M.; Brandi, R.; Alfano, O.; Cassano, A. Mass transfer limitations in photocatalytic reactors employing titanium dioxide suspensions: II. External and internal particle constrains for the reaction. Chem. Eng. J. 2008, 136, 242-255. [CrossRef]

123. Yao, P.; Choo, K.-H.; Kim, M.-H. A hybridized photocatalysis-microfiltration system with iron oxide-coated membranes for the removal of natural organic matter in water treatment: Effects of iron oxide layers and colloids. Water Res. 2009, 43, 4238-4248. [CrossRef]

124. Athanasekou, C.P.; Morales-Torres, S.; Likodimos, V.; Romanos, G.E.; Pastrana-Martinez, L.M.; Falaras, P.; Dionysiou, D.D.; Faria, J.L.; Figueiredo, J.L.; Silva, A.M.T. Prototype composite membranes of partially reduced graphene oxide/ $\mathrm{TiO}_{2}$ for photocatalytic ultrafiltration water treatment under visible light. Appl. Catal. B Environ. 2014, 158-159, 361-372. [CrossRef]

125. Pastrana-Martínez, L.M.; Morales-Torres, S.; Figueiredo, J.L.; Faria, J.L.; Silva, A.M.T. Graphene oxide based ultrafiltration membranes for photocatalytic degradation of organic pollutants in salty water. Water Res. 2015, 77, 179-190. [CrossRef] [PubMed]

126. Kaplan Bekaroglu, S.S.; Yigit, N.O.; Harman, B.I.; Kitis, M. Hybrid Adsorptive and Oxidative Removal of Natural Organic Matter Using Iron Oxide-Coated Pumice Particles. J. Chem. 2016, 2016, 3108034. [CrossRef]

127. Uyguner, C.S.; Suphandag, S.A.; Kerc, A.; Bekbolet, M. Evaluation of adsorption and coagulation characteristics of humic acids preceded by alternative advanced oxidation techniques. Desalination 2007, 210, 183-193. [CrossRef]

128. Moncayo-Lasso, A.; Sanabria, J.; Pulgarin, C.; Benítez, N. Simultaneous E. coli inactivation and NOM degradation in river water via photo-Fenton process at natural $\mathrm{pH}$ in solar CPC reactor. A new way for enhancing solar disinfection of natural water. Chemosphere 2009, 77, 296-300. [CrossRef]

129. Gelover, S.; Gómez, L.A.; Reyes, K.; Teresa Leal, M. A practical demonstration of water disinfection using $\mathrm{TiO}_{2}$ films and sunlight. Water Res. 2006, 40, 3274-3280. [CrossRef]

130. Fernández-Ibáñez, P.; Sichel, C.; Polo-López, M.I.; de Cara-García, M.; Tello, J.C. Photocatalytic disinfection of natural well water contaminated by Fusarium solani using $\mathrm{TiO}_{2}$ slurry in solar CPC photo-reactors. Catal. Today 2009, 144, 62-68. [CrossRef]

131. Chong, M.N.; Jin, B.; Chow, C.W.; Saint, C. Recent developments in photocatalytic water treatment technology: A review. Water Res. 2010, 44, 2997-3027. [CrossRef]

132. Murray, C.A.; Parsons, S.A. Advanced oxidation processes: Flowsheet options for bulk natural organic matter removal. Water Supply 2004, 4, 113-119. [CrossRef]

133. Legrini, O.; Oliveros, E.; Braun, A.M. Photochemical processes for water treatment. Chem. Rev. 1993, 93, 671-698. [CrossRef]

134. Chin, A.; Bérubé, P.R. Removal of disinfection by-product precursors with ozone-UV advanced oxidation process. Water Res. 2005, 39, 2136-2144. [CrossRef] [PubMed]

135. Lamsal, R.; Walsh, M.E.; Gagnon, G.A. Comparison of advanced oxidation processes for the removal of natural organic matter. Water Res. 2011, 45, 3263-3269. [CrossRef] [PubMed]

136. Toor, R.; Mohseni, M. UV- $\mathrm{H}_{2} \mathrm{O}_{2}$ based AOP and its integration with biological activated carbon treatment for DBP reduction in drinking water. Chemosphere 2007, 66, 2087-2095. [CrossRef]

137. Murray, C.A.; Parsons, S.A. Removal of NOM from drinking water: Fenton's and photo-Fenton's processes. Chemosphere 2004, 54, 1017-1023. [CrossRef] [PubMed]

138. Goslan, E.H.; Gurses, F.; Banks, J.; Parsons, S.A. An investigation into reservoir NOM reduction by UV photolysis and advanced oxidation processes. Chemosphere 2006, 65, 1113-1119. [CrossRef]

139. Moncayo-Lasso, A.; Pulgarin, C.; Benítez, N. Degradation of DBPs' precursors in river water before and after slow sand filtration by photo-Fenton process at pH 5 in a solar CPC reactor. Water Res. 2008, 42, 4125-4132. [CrossRef]

140. Zepp, R.G.; Faust, B.C.; Hoigne, J. Hydroxyl radical formation in aqueous reactions (pH 3-8) of iron(II) with hydrogen peroxide: The photo-Fenton reaction. Environ. Sci. Technol. 1992, 26, 313-319. [CrossRef]

141. Wardman, P.; Candeias, L.P. Fenton Chemistry: An Introduction. Radiat. Res. 1996, 145, 523-531. [CrossRef]

142. Park, S.; Yoon, T.-I. The effects of iron species and mineral particles on advanced oxidation processes for the removal of humic acids. Desalination 2007, 208, 181-191. [CrossRef]

143. Clarizia, L.; Russo, D.; Di Somma, I.; Marotta, R.; Andreozzi, R. Homogeneous photo-Fenton processes at near neutral pH: A review. Appl. Catal. B Environ. 2017, 209, 358-371. [CrossRef]

144. Fukushima, M.; Tatsumi, K.; Nagao, S. Degradation Characteristics of Humic Acid during Photo-Fenton Processes. Environ. Sci. Technol. 2001, 35, 3683-3690. [CrossRef] [PubMed]

145. Wang, G.-S.; Hsieh, S.-T.; Hong, C.-S. Destruction of humic acid in water by UV light—catalyzed oxidation with hydrogen peroxide. Water Res. 2000, 34, 3882-3887. [CrossRef]

146. Carr, S.A.; Baird, R.B. Mineralization as a mechanism for TOC removal: Study of ozone/ozone-peroxide oxidation using FT-IR. Water Res. 2000, 34, 4036-4048. [CrossRef]

147. Otieno, B.; Apollo, S.; Kabuba, J.; Naidoo, B.; Ochieng, A. Ozonolysis Post-Treatment of Anaerobically Digested Distillery Wastewater Effluent. Ozone Sci. Eng. 2019, 41, 551-561. [CrossRef]

148. Ratpukdi, T.; Siripattanakul, S.; Khan, E. Mineralization and biodegradability enhancement of natural organic matter by ozoneVUV in comparison with ozone, VUV, ozone-UV, and UV: Effects of pH and ozone dose. Water Res. 2010, 44, 3531-3543. [CrossRef] [PubMed] 
149. Bircher, K.; Tumas, W.; Tolman, C. Figures-of-Merit for the Technical Development and Application of Advanced Oxidation Technologies for Both Electric- and Solar-Driven Systems-(IUPAC Technical Report). Pure Appl. Chem. 2001, 73, 627-637.

150. Uyguner, C.S.; Bekbolet, M. Evaluation of humic acid photocatalytic degradation by UV-vis and fluorescence spectroscopy. Catal. Today 2005, 101, 267-274. [CrossRef]

151. Gottschalk, C.; Libra, J.; Saupe, A. Ozonation of Water and Waste Water: A Practical Guide to Understanding Ozone and Its Application, 2000; 189.

152. Yang, Y.; Pignatello, J.J. Participation of the Halogens in Photochemical Reactions in Natural and Treated Waters. Molecules 2017, 22, 1684. [CrossRef]

153. Grebel, J.E.; Pignatello, J.J.; Mitch, W.A. Effect of Halide Ions and Carbonates on Organic Contaminant Degradation by Hydroxyl Radical-Based Advanced Oxidation Processes in Saline Waters. Environ. Sci. Technol. 2010, 44, 6822-6828. [CrossRef]

154. Treguer, R.; Tatin, R.; Couvert, A.; Wolbert, D.; Tazi-Pain, A. Ozonation effect on natural organic matter adsorption and biodegradation-Application to a membrane bioreactor containing activated carbon for drinking water production. Water Res. 2010, 44, 781-788. [CrossRef]

155. Yan, W.-Y.; Zhou, Q.; Chen, X.; Yang, Y.; Zhang, Y.; Huang, X.-J.; Wu, Y.-C. Size-Controlled $\mathrm{TiO}_{2}$ nanocrystals with exposed $\{001\}$ and $\{101\}$ facets strongly linking to graphene oxide via p-Phenylenediamine for efficient photocatalytic degradation of fulvic acids. J. Hazard. Mater. 2016, 314, 41-50. [CrossRef] [PubMed]

156. Turkten, N.; Bekbolet, M. Photocatalytic performance of titanium dioxide and zinc oxide binary system on degradation of humic matter. J. Photochem. Photobiol. A Chem. 2020, 401, 112748. [CrossRef]

157. Valencia, S.; Marín, J.; Restrepo, G. Photocatalytic Degradation of Humic Acids with Titanium Dioxide Embedded into Polyethylene Pellets to Enhance the Postrecovery of Catalyst. Environ. Eng. Sci. 2017, 35, 185-193. [CrossRef]

158. Asha, R.C.; Vishnuganth, M.A.; Remya, N.; Selvaraju, N.; Kumar, M. Livestock Wastewater Treatment in Batch and Continuous Photocatalytic Systems: Performance and Economic Analyses. Water Air Soil Pollut. 2015, 226, 132. [CrossRef]

159. Giménez, J.; Bayarri, B.; González, Ó.; Malato, S.; Peral, J.; Esplugas, S. Advanced Oxidation Processes at Laboratory Scale: Environmental and Economic Impacts. ACS Sustain. Chem. Eng. 2015, 3, 3188-3196. [CrossRef]

160. Izadifard, M.; Achari, G.; Langford, C.H. Application of Photocatalysts and LED Light Sources in Drinking Water Treatment. Catalysts 2013, 3, 726-743. [CrossRef]

161. Tokode, O.; Prabhu, R.; Lawton, L.; Robertson, P. UV LED Sources for Heterogeneous Photocatalysis. In Environmental Photochemistry Part III; Springer: Berlin/Heidelberg, Germany, 2014. 